\title{
What is Really Happening with Global Inequality?
}

\begin{abstract}
We use the latest available data from the World Income Inequality Database 3.4 and the Penn World Tables 9.0 to examine some of the core issues and concerns that have animated research on global inequality. We begin by reviewing the evidence on trends in within-country inequality, drawing out some of the implications of this for our thinking about inequality and economic development. We examine betweencountry inequality, computing updated estimates of trends in both unweighted and population-weighted between-country inequality. The data reveal that inequality between countries increased across the latter half of the twentieth century, then turned to decline measurably thereafter. We show that this decline is robust to a range of methodological and measurement decisions identified as important in previous research. We then examine estimates of true global inequality, situating these in relation to lower- and upper-bound estimates of global inequality. We conclude by noting the critical and contested role of globalization in inequality reduction. KEYWORDS global inequality, within-country inequality, between-country inequality
\end{abstract}

A few centuries ago the global distribution of income looked quite different than it does today. By current standards and metrics, the world was poor, and most of the inequality in the world distribution of income was attributable to within-nation income differences. That is, imagine that we had income data on every individual or household in the world. ${ }^{1}$ With that, one could calculate some measure of global income inequality. If we took that measure and decomposed it into its within- and between-country components, we would find that the within component was much larger than the between component. As Milanovic (2013a) has put it, it was a world in which "class" mattered far more than "location" (i.e, the country in which one lived) for one's position in the global distribution of income. Indeed, as recently as the first half of the nineteenth century, our best estimates suggest that something on the order of $80 \%$ of global inequality was within country, and only about $20 \%$ was between (Bourguinon and Morrisson 2002). Simply put, the gap between rich and poor within countries made a much larger contribution to global inequality than the gap between rich and poor countries.

Over the next two centuries, this changed dramatically and fundamentally. The Industrial Revolution and the sustained economic growth that characterized Western nations in the nineteenth century led to a "Great Divergence" between the West and the rest of the world (Pomeranz 200I). In that process, income differences between societies ballooned to dominate the world distribution of income (Milanovic 2011, 2016a). Presently, betweencountry income inequality accounts for around two-thirds of total global inequality. In other words, if we eliminated inequality within countries entirely-if we took the income

Sociology of Development, Vol. 4, Number 3, pps. 26I-28I. electronic ISSN 2374-538X. (c) 2018 by the Regents of the University of California. All rights reserved. Please direct all requests for permission to photocopy or reproduce article content through the University of California Press's Reprints and Permissions web page, www.ucpress.edu/journals. php?p=reprints. DOI: https://doi.org/I0.1525/sod.2018.4.3.26I. 
generated in each society and divided it equally among the members of that society, and did that for every society around the world-global inequality today would decline only by about a third. Moreover, over half of the variation in personal incomes globally is accounted for simply by the average national income of one's country of residence (Milanovic 2013a). The combined explanatory power of a collection of personal characteristics that are well known to be associated with one's income-social class, gender, race, education, family background, and so on-pale in comparison to that of a single variable today: the country in which you live.

Over the past two decades, research in sociology and economics has generated considerable debate over the empirics of global inequality and the factors underlying these trends (e.g., Korzeniewicz and Moran 1997; Firebaugh 2003; Firebaugh and Goesling 2004; Anand and Segal 2008; Dowrick and Akmal 2005). While there is a scholarly consensus that global income inequality had been rising for most of the twentieth century, the trajectory of global inequality in the last decades of the twentieth century has been a subject of debate. Given an emerging consensus that the last decades of the past century saw an increase in income inequality within the typical society (Cornia, Addison, and Kiiski 2003; Firebaugh 2003; Goesling 200I), much of the debate about contemporary inequality trends centers on the between-country component. Some have found that global inequality declined in the last two decades of the twentieth century (e.g., Firebaugh 1999, 2003; Goesling 2001; Melchior and Telle 2001; Sala-i-Martin 2002), while others have argued that such findings are sensitive to methodological decisions, such as the use of purchasing power parity (PPP) versus market exchange rates, how PPP is constructed (i.e., the Geary-Khamis vs. Eltetö-Köves-Szulc methods), the use of population weights, and the inclusion of China (Anand and Segal 2008; Arrighi, Silver, and Brewer 2003; Wade 2004; Clark 2011; Dowrick and Akmal 2005; Firebaugh 2003; Hung and Kucinskas 2011; Melchior and Telle 2001).

In this article, we revisit this debate, using the latest available data and ask: What is really happening with global inequality? We proceed in three steps. First, we briefly review the evidence on trends in within-country inequality, noting that, on a global scale, the transition of employment out of agriculture into industry and services is rapidly nearing completion and drawing out some of the implications of this for our understanding of global inequality. Second, we examine between-country inequality, computing updated estimates of trends in unweighted and population-weighted between-country inequality using data from the Penn World Tables (PWT) 9.0 (Feenstra, Inklaar, and Timmer 2015). These data reveal that inequality between countries increased across the latter half of the twentieth century, then turned to decline measurably thereafter. We show that this decline is robust to a range of methodological and measurement decisions identified as important in previous research. Finally, we examine extant estimates of "true" global inequality, situating these in relation to theoretical lower- and upper-bound estimates that we derive from the latest data.

\section{WITHIN-COUNTRY INCOME INEQUALITY}

Studies of within-country income inequality have generally found that inequality has increased in most societies since the I970s. For example, using data from the World Income 
Inequality Database (WIID) and focusing on the subset of societies for which we have the most reliable data, Cornia, Addison, and Kiiski (2003) find that income inequality increased in about two-thirds of the world's societies. Inequality grew in developed and many developing countries, and in nearly all post-communist societies. Similarly, using the University of Texas Inequality Project Data on pay inequality, Galbraith (20II) finds that inequality increased in the typical country and increased more steeply in developing societies than in developed ones. Finally, using the "AlltheGinis" data set, Milanovic (2016b) likewise reports that income inequality grew in about two-thirds of the countries under examination since the late I980s. Both Cornia, Addison, and Kiiski (2003) and Milanovic (2016b) find that the inequality upswing was typically substantively meaningful, at 5 Gini points or greater in most of the countries experiencing rising inequality. ${ }^{2}$ What does an increase in income inequality of 5 Gini points mean? Expressed in terms of a cake-sharing game in which two people divide a cake between them, if Person A received the smaller slice at Time I, a rise of 5 Gini points means that Person A would receive $2.5 \%$ less cake at Time 2 (Subramanian 2002).

This upswing in inequality occurring across countries at various levels of development has raised new questions about the relationship between inequality and long-run economic development. For some time, social scientific thinking on this had been dominated by the familiar image of the Kuznets Curve (Kuznets 1955), the central insight being that industrialization is associated with a variety of compositional changes that generate an inverted-U-shaped relationship between inequality and development. "Starting" from a low level of development in which the low productivity/income agrarian sector dominates, the shift of the labor force in the course of industrialization into the higher productivity/income manufacturing and service sectors produces, mechanically, rising then falling inequality over the course of the industrial transition. ${ }^{3}$ The implications of this classic account for contemporary developing and developed societies has been a subject of regular and recurring debate. Some find support for an inverted$\mathrm{U}$ relationship between economic development and income inequality (e.g., Ahluwalia 1976; Nielsen and Alderson 1995; Barro 2008), while others argue that there is scant evidence, longitudinally, that present-day developing societies conform to the Kuznetsian pattern and that Kuznets's argument is, in any case, poorly equipped to explain the increase in inequality that many developed societies have experienced since the i970s (e.g., Alderson and Nielsen 2002; Fields 2001; Deininger and Squire 1998; Harrison and Bluestone 1988; Bluestone 1990).

What should we infer from this debate, and how should we think about the relationship between inequality and development today? Viewed globally, we think it critical to note that the industrial transition-the shift out of agriculture and into industry and services, which Kuznets saw as the central mechanism lying behind the Kuznets Curve-is drawing to a close. Sometime in the 1980 -for the first time in thousands of years-more people in the world worked outside the agricultural sector than within it. Data on employment by sector collected by the International Labor Organization (2018) reveals that, by 200I, agriculture was no longer even the modal sector of employment globally. In that year, employment in services surpassed that in agriculture. This indicates that, at a global level, we are presently 
beyond the point at which the dualism between the agriculture and non-agricultural sectors would be expected to drive inequality upward in the typical developing society.

A quick look at the data on within-country inequality bears this out. In the left panel of Figure I, we pool all of the data that we have on income inequality for the 1960 s from version 3.4 of the WIID (UNU-WIDER 2017) and plot this against a measure of real GDP/ Capita (20II USD) from version 9.0 of the PWT (Feenstra, Inklaar, and Timmer 2015). In the right panel, we do the same for the present decade. As one can note, in the 1960s, the familiar inverted $U$ of the Kuznets Curve emerges in these data. Doing the same for every decade (not shown), one can observe that, by the 20 Ios, the world's societies have shifted notably to the right (i.e., average income increases) and most societies have moved well into the industrial transition (i.e., to the right of the inflection point of the Kuznets Curve). In Figure 2, we show how the level of inequality has changed over the past six decades. Consistent with the literature on within-country inequality, we see that inequality, on average, declined across the 1960 s, the I970s, and into the 1980 s, after which it turned to increase. While the reader should not put too fine a point on this, the increase that we see between the 1980 s and 20ros-an increase at the median of about 4.5 Gini points-is of roughly the same order as that reported by Cornia, Addison, and Kiiski (2003) and Milanovic (2016b), based on a far more careful approach to the data. ${ }^{4}$

Presently, then, we live in a world in which richer societies tend to have lower levels of inequality than poorer societies, but also one in which many societies, rich and poor alike, are on a trajectory of rising inequality. Just as there is nothing in Kuznets's original argument that would lead us to anticipate the U-turn on inequality that began in many rich societies in the 1970s, it is not obvious, within this framework, how one might reconcile the increase in inequality in many developing societies with the fact that they are already well into the industrial transition; that is, beyond the point at which dualism between agriculture and non-agricultural sectors would be expected to drive inequality upward in the typical developing society. ${ }^{5}$ Interestingly, the post-industrial-transition distribution of the labor force across sectors in these societies appears to have been evolving rather differently than it did in
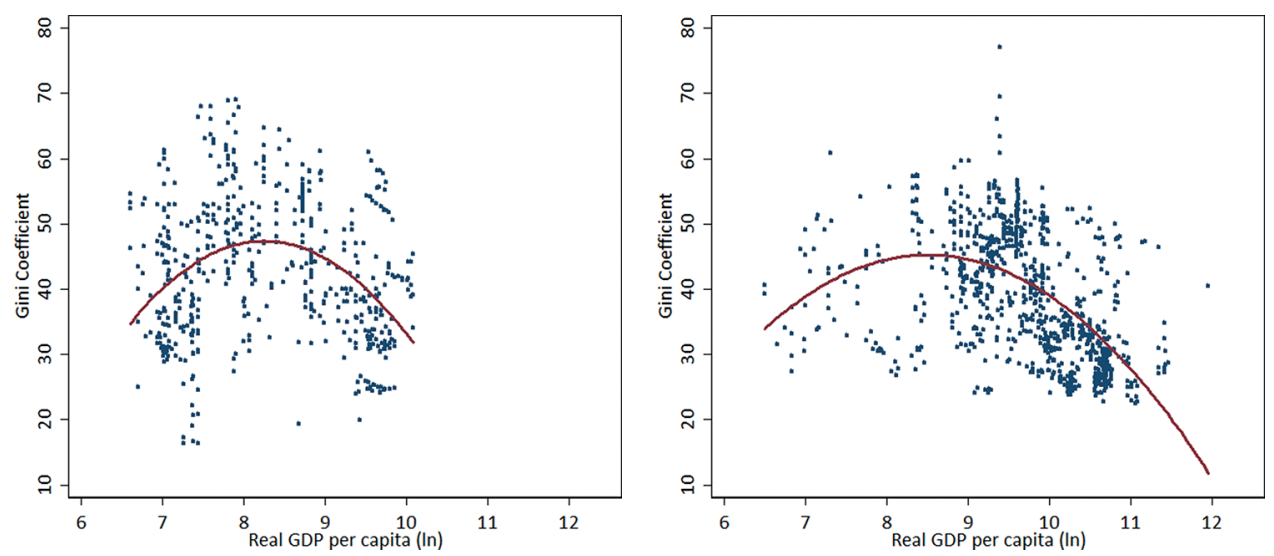

FIGURE 1. Inequality and Development in the World Income Inequality Database 3.4, All Observations Available for the r 960 s and the 2010 s 


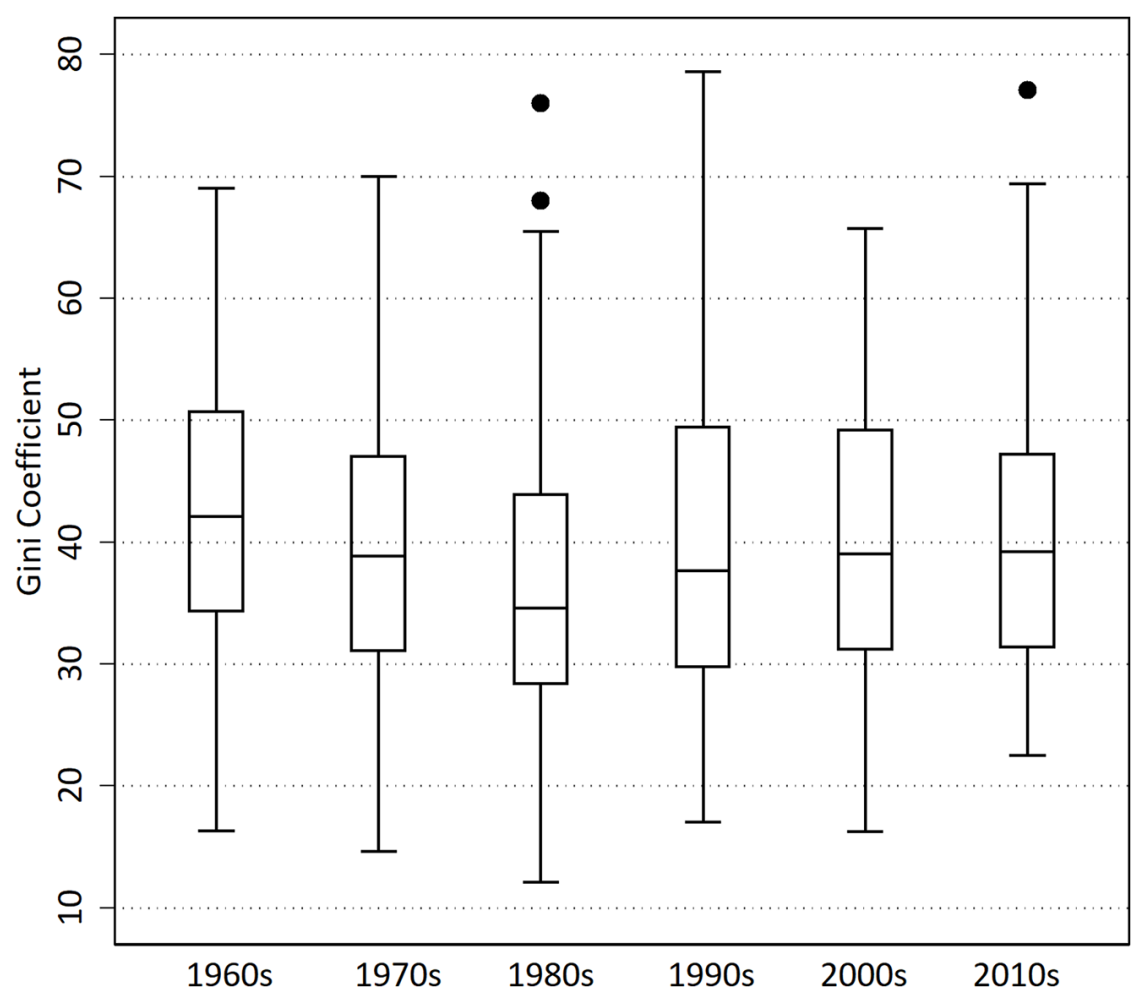

FIGURE 2. All of the Data from the World Income Inequality Database $3.4(\mathrm{~N}=7447$, 1960-2014)

the rich societies. Scholars have recently begun to document deindustrialization in developing nations, particularly in Latin America and Sub-Saharan Africa (Brady, Kaya, and Gereffi 20II; Rodrik 2016). This process of declining manufacturing employment, termed "premature deindustrialization," is striking because it has begun at a lower level of economic development than it did in rich societies, a phenomenon that Rodrik (2016) explains in terms of heightened global competition. The combination of declining primary- and secondary-sector employment in developing societies, alongside the rapid growth of tertiary-sector employment is a likely culprit in rising inequality in such societies. The greater heterogeneity of the rapidly growing service sector, from high-end information technology services to informal retail services, has long been argued to have contributed to the upswing in inequality in developed societies (e.g., Levy and Murname 1992; Singelmann et al. 1993; Alderson and Nielsen 2002). In sum, then, the post-industrial-transition world that we have moved into is one in which there is very little evidence that economic development will, in the near term, result in a reduction in inequality within the typical society, developed and developing alike.

\section{BETWEEN-COUNTRY INCOME INEQUALITY}

If income inequality has been rising within the typical society, what of inequality between countries? In fact, much of the debate over recent trends in global inequality has centered precisely on the between-country component (Korzeniewicz and Moran 1997; 
Firebaugh 1999, 2003; Firebaugh and Goesling 2004; Anand and Segal 2008; Dowrick and Akmal 2005). Recent work on the subject suggests that population-weighted between-country inequality in PPP-adjusted international dollars has been declining since the last decades of the twentieth century (Firebaugh 2003; Sala-i-Martin 2002; Hung and Kucinskas 20II; cf. Clark 20II). However, other scholars have argued that the finding of declining between-country inequality may have been driven by a range of methodological and measurement issues: the choice of index in PPP construction (Dowrick and Akmal 2005; Anand and Segal 2008); the use of PPP exchange rates versus market exchange rates (Firebaugh 1999; Korzeniewicz and Moran 2000; Wade 2004; Dowrick and Akmal 2005); population-weighting (Babones 2002; Wade 2004); and the exceptional growth of China (Babones 2002; Clark 2011). In what follows, we compute updated measures of between-country inequality using the latest data from the PWT. We find that between-country inequality has declined, but only since 2000 . We then show that this decline after 2000 is robust to the methodological and measurement issues raised in the literature.

\section{Updates to the Penn World Tables' Treatment of Non-Benchmark Years}

The main data come from the latest PWT. The PWT employs surveys from the International Comparison Program (ICP) to compute PPP-adjusted GDP per capita. Before presenting the updated estimates of between-country inequality, a brief discussion of how the PWT uses the ICP price data is in order. The ICP has conducted seven cross-national price surveys since 1970, with progressively increasing country-coverage (1970, 1975, 1980, 1985, 1996, 2005, 2011). These price surveys provide data on the relative prices of a basket of goods and enable the computation of GDP figures that adjust for relative price levels across countries. This purchasing-power adjustment is designed to provide a more accurate indication of relative standards of living across countries than can be derived using exchange rates. However, the GDP figures for non-benchmark years cannot be estimated directly because relative price data are not available.

In previous versions of the PWT (7 and older), GDP figures for non-benchmark years were estimated by using the single latest ICP benchmark year and then extrapolating using relative national inflation rates for the non-benchmark years. This method is similar to that used by the World Bank to arrive at estimates of GDP per capita in PPP-adjusted (international) dollars. Starting from PWT 8.०, the PPPs are estimated using data not only from the most recent ICP price survey, but also from earlier surveys. PPP estimates are interpolated or extrapolated for each country using the nearest year in which the country participated in an ICP survey. To cite an example from the user guide, if a country participated in the 1996 and 2005 price surveys, PPP data for the years between 1996 and 2005 are interpolated using relative inflation rates such that the PPP estimates for the intervening years are consistent with those in 1996 and 2005. For the years before 1996 and after 2005, PPP data are extrapolated using relative inflation rates. In sum, PWT 9.0 employs information from the latest 20II ICP survey, but also uses information from earlier surveys. This use of all available ICP survey data is a substantial departure from the data used in studies that rely on earlier versions of PWT or World Bank data. ${ }^{6}$ 
Estimates of Population-Weighted Between-Country Inequality using PWT 9.0

Figure 3 presents our calculation of population-weighted between-country inequality in PPP-adjusted GDP per capita for three different samples: a series beginning in 1950 with complete data on 6I countries, a series beginning in 1960 with complete data on II countries, and a series beginning in 1970 with complete data on 156 countries. The countries in these series contain, respectively, $74 \%, 87 \%$, and $95 \%$ of world population in 1987 , the approximate midpoint of the data. The 1970 series has considerably more countries than the 1950 sample because GDP per capita data are available for a wider range of countries in later years. It is also worth noting that data on the post-communist countries that split from the Soviet Union are not available in the PWT. Figure 3 suggests a clear pattern in betweencountry inequality, regardless of which sample is used. In the 1970 series, weighted betweencountry inequality oscillates around a Gini of 0.6 and declines steeply after 2000, reaching below 0.5 in 2014. The 1950 and 1960 series suggest a steady upward trend in inequality until 1990, followed by a steep decline after 2000 . In sum, the results presented in Figure 3 suggest that weighted between-country inequality has declined substantially in recent years. However, in contrast to previous studies that documented declines in the last few decades of the twentieth century, we find that inequality only declined appreciably after 2000 . In what follows, we examine whether this decline in between-country inequality is sensitive to PPP construction, choice of PPPs over exchange rates, population weighting, or the inclusion of China.

\section{Construction of PPP Rates: Penn World Table versus World Bank Data}

Among other differences between the two main data sources used to measure betweencountry inequality, the PWT and the World Bank use different methods to construct PPP

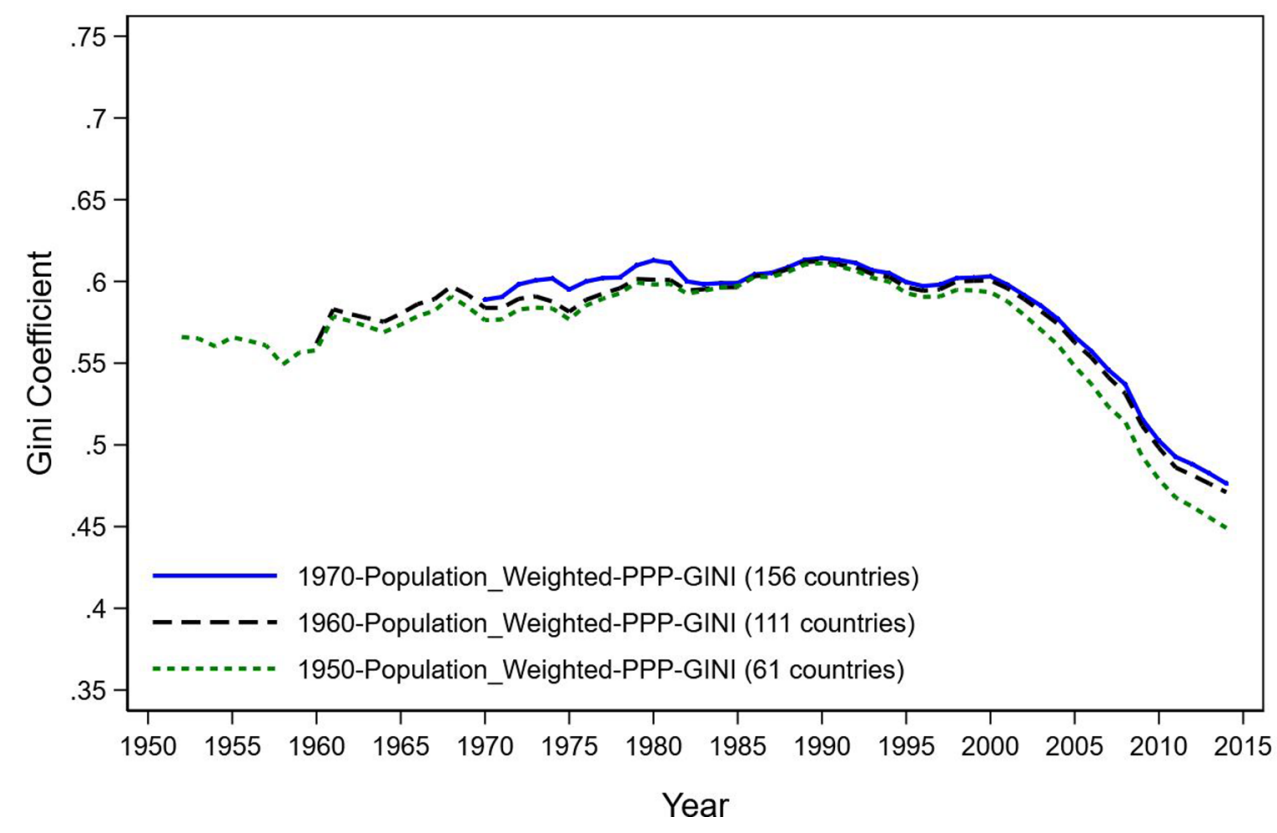

FIGURE 3. Trend in Population-Weighted Between-Country Inequality 
rates. Traditionally, the PWT has used the Geary-Khamis (GK) index method, while more recent World Bank data relies on the Eltetö-Köves-Szulc (EKS) method. This is, potentially, an important difference, as it is the PPP rate, of course, that renders GDP figures comparable. Research has shown that the GK index method overestimates the real income of poorer nations and biases estimates of international inequality downward (Dowrick and Akmal 2005; Anand and Segal 2008). The EKS method does not suffer from this form of bias. From PWT 8.0 onward, a combination of EKS and GK methods are used to arrive at PPP-adjusted GDP figures. In contrast, the World Bank does not use GK index methods. Also, as mentioned earlier, the PWT uses information from previous ICP price surveys while the World Bank only uses the information from the latest ICP survey (2011). Previous work has shown that the calculation of trends in between-country inequality is sensitive to the choice of index method (Dowrick and Akmal 2005; Anand and Segal 2008). For example, Dowrick and Akmal (2005) show that between-country inequality declines between I980 and 1997 when using the PWT's older GK index method for PPP construction and that when the substitution bias associated with the GK index method is corrected, there is no discernible change in inequality.

To address these concerns, we compare the trends in population-weighted betweencountry inequality using both PWT 9.0 and World Bank data. World Bank PPP-adjusted GDP figures are only available from 1990 onward. Also, the sample of countries available in the World Bank data is different from that contained in the PWT. Therefore, the final sample of countries for this comparison is reduced to the 138 countries available in both sources. Figure 4 plots the trends in weighted between-country inequality using both data sources from 1990 onward. The plots suggest no major differences in trends in inequality in the last

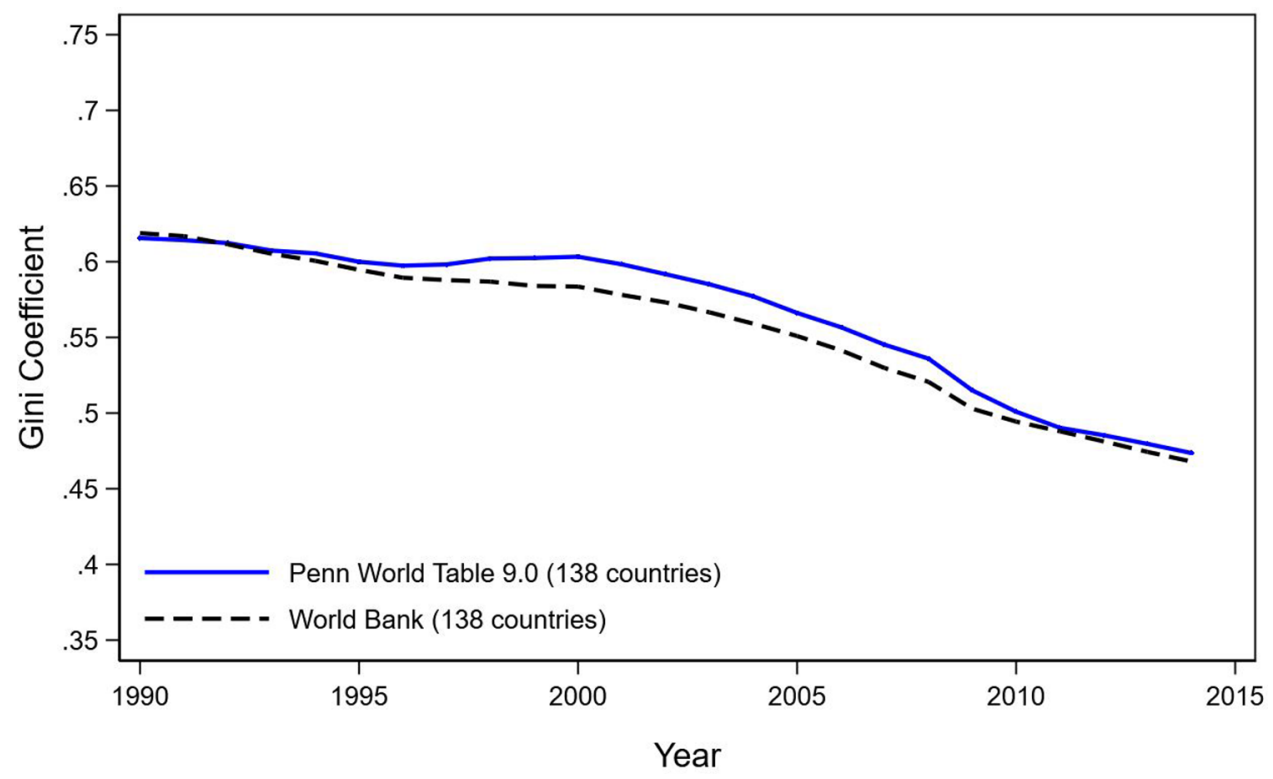

FIGURE 4. Trend in Population-Weighted Between-Country Inequality: Penn World Tables and World Bank PPP Methods Compared 
25 years. The World Bank data suggest that inequality started to decline earlier than what the PWT data indicate, but both suggest substantively meaningful declines in inequality, on the order of over Io Gini points. In sum, Figure 4 indicates that the choice of data source and PPP index method is not driving the post-2000 decline in between-country inequality we observed above.

\section{Purchasing Power Parity or Market Exchange Rates}

Another point of contention in the literature on global inequality has concerned the choice of whether to use PPP exchange rates or official market exchange rates to convert currencies (Firebaugh 1999; Korzeniewicz and Moran 2000; Arrighi, Silver, and Brewer 2003). Put simply, PPP exchange rates take into account domestic price differences between countries while market exchange rates do not. The decision to use one over the other hinges on the type of question we are interested in. If we are interested in comparing average levels of welfare across countries, the use of market exchange rates would tend to underestimate the real income of individuals in poorer countries because prices for goods and services are generally lower in poorer countries (Firebaugh 1999; Melchior and Telle 200I). In this case, the use of a consumption-based PPP exchange rate would better capture differences in standards of living. However, if we are interested in a measure of the "relative command that inhabitants of different countries have [over world income]," then the use of market exchange rates would be more appropriate (Korzeniewicz and Moran 1997:I0II; Arrighi, Silver, and Brewer 2003). Most importantly, prior research suggests that the decision to use PPPs or market exchange rates matters crucially for the conclusions we draw about trends in international inequality (Firebaugh 1999).

In Figure 5, we examine whether the use of official market exchange rates in the computation of population-weighted between-country inequality affects our conclusions about the trend in inequality. Figure 5 reproduces the original weighted between-country inequality series using PPP GDP per capita figures along with another series that uses market exchange rate GDP per capita. Both plots are for the 1970 sample of 156 societies. While the measured level of between-country inequality is higher when market exchange rates are used, the dynamics are very similar. By the market exchange rate series, between-country inequality starts to gradually decline in the early I990s before declining more sharply after 2000 . While the extent of the decline is less pronounced in the market exchange rate series than in the PPP series, our analysis indicates that-regardless of how we conceptualize between-country inequality, either as disparities in welfare conditions or disparities in the command over world income-inequality has declined since 2000.

\section{Population-Weighting}

Milanovic (2013a) distinguishes between "Concept I" and "Concept 2" versions of between-country international inequality. Concept $\mathrm{I}$ inequality is simple international inequality (i.e., inequality in average income between countries) while Concept 2 inequality is population-weighted inequality between countries. In other words, the unit of analysis in Concept I inequality is the country, while the unit of analysis in Concept 2 inequality is the average individual. In Concept $\mathrm{I}$, each country is given equal weight in the 


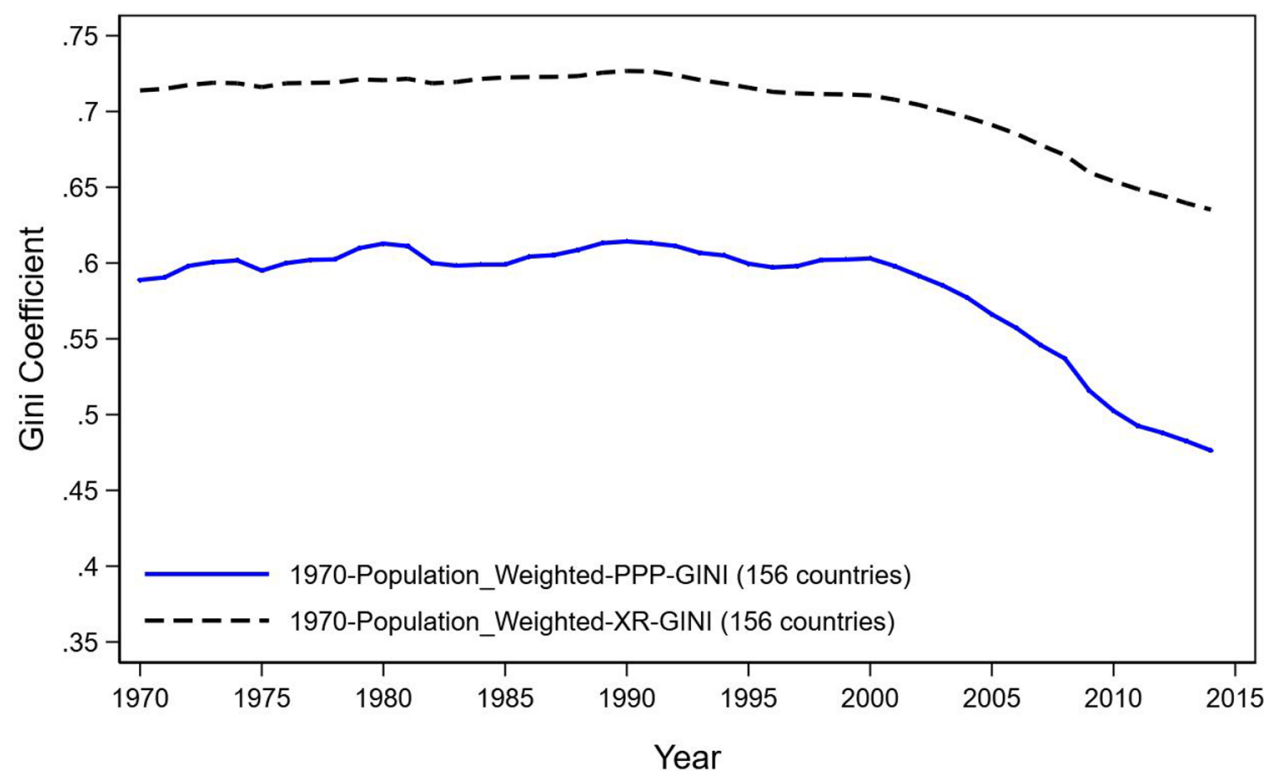

FIGURE 5. Trend in Population-Weighted Between-Country Inequality: PPP and Market Exchange Rate Methods Compared

computation of the dispersion measure, so that, for example, China and Qatar have the same weight. This unweighted measure of inequality is particularly useful when we are interested in convergence/divergence processes between countries or comparing the performance of different economies. For example, analyses that employ a world-systems perspective and are interested in the mobility of nation-states in the world-economy typically use unweighted GDP per capita figures (Wallerstein 2004; Babones 2005; Clark 2016). As Babones (2002) demonstrates, trends in unweighted international inequality do not necessarily have to follow trends in populationweighted between-country inequality. Indeed, if the decline in population-weighted inequality after 2000 is being driven by a handful of high-growth, populous countries, unweighted inequality could still be increasing. In Figure 6, we examine whether the decline in between-country inequality we observe after 2000 in Figure 3 is the result of population-weighting.

Figure 6 displays trends in unweighted between-country inequality for the 1950 and 1960 samples using both PPP rates and market exchange rates. In both of the PPP samples, between-country inequality, while fluctuating from year to year, generally increases until 2000 and declines thereafter. The two exchange rate series are a bit more difficult to characterize, suggesting that, by this measure, simple international inequality-which we know had been rising for centuries-had plateaued or hit a ceiling in the late twentieth century. Here too, however, we see a small decline of a few Gini points after 2000 . Overall, the results presented in Figure 5 suggest that Concept $\mathrm{I}$ inequality (i.e., unweighted international inequality) has declined along with Concept 2 inequality (i.e., weighted between-country inequality) in the last two decades or so. 


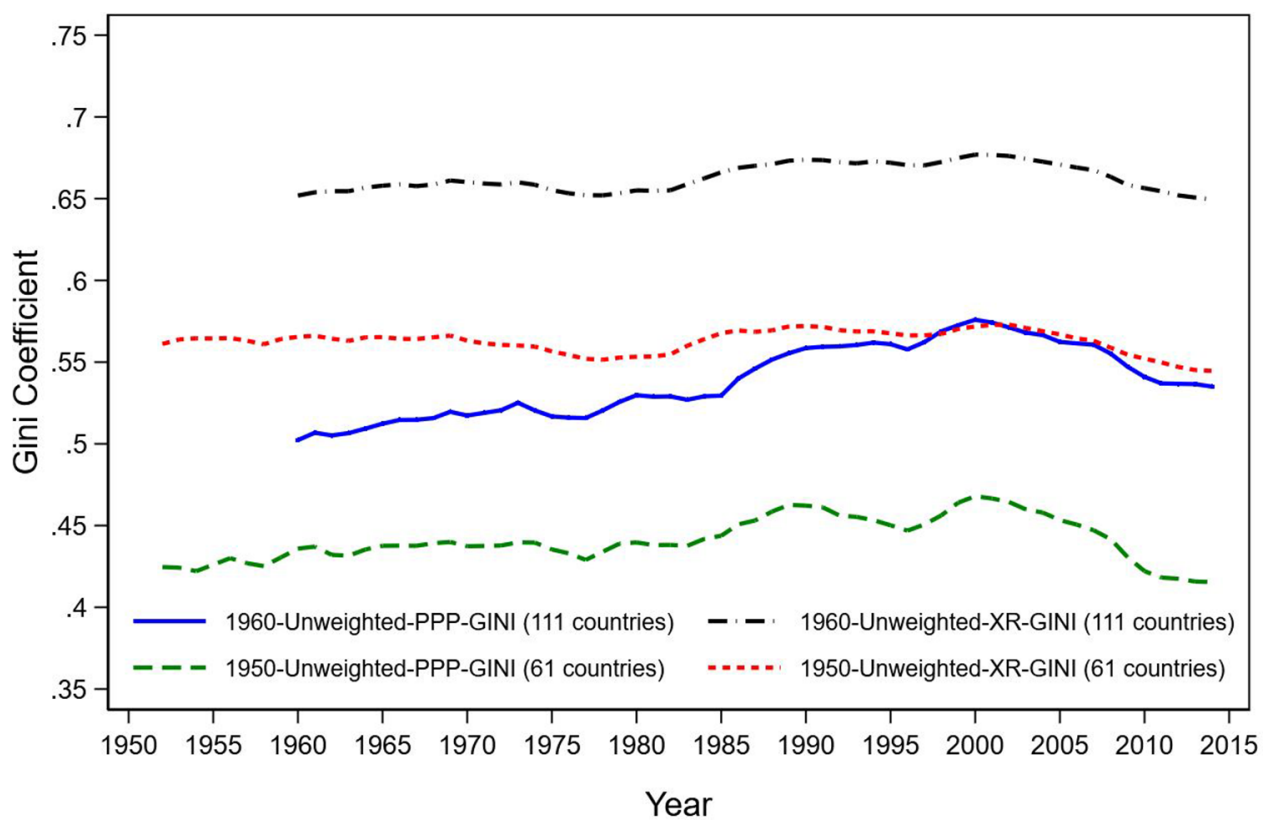

FIGURE 6. Trend in Unweighted International (Between-Country) Inequality

\section{The "Chindia" Effect}

China has maintained a growth rate that is consistently above the world average for the past four decades (World Bank 2017; Hung 2015). Several studies have suggested that, owing to its large population, population-weighted between-country inequality is highly sensitive to the inclusion/exclusion of China (Peacock, Hoover, and Killian 1988; Schultz 1998; Melchior and Telle 200I; Clark 20II; Hung and Kucinskas 20II). For example, Clark (2011) finds that with the inclusion of China, between-country inequality declined between 1990 and 1999 and, with China excluded, between-country inequality increased across the same period. Similarly, Hung and Kucinskas (201I) find that, between 1980 and 2004, between-country inequality declined with China and India included, but, when both countries are excluded, inequality increased until 2000 before leveling out.

Given the likely outsized influence of very large countries such as China and India on our measurement of weighted between-country inequality, it is worthwhile to examine their effect on the trend in inequality we observed in Figure 3. Figure 7 thus displays three series using the 1970 sample: the weighted between-country inequality for the full sample; with China excluded; and with both China and India excluded. China and India have meaningful effects on both the level and trajectory of between-country inequality. With the exclusion of China, and both China and India, inequality is lower in 1970, increases until around 2000, and then generally declines thereafter. The exclusion of China and India, interestingly enough, would lead us to underestimate inequality for much of the latter part of the twentieth century and to underestimate the extent of the decline in between-country inequality in the twenty-first century. That said, it is also clear that, even if one were inclined to exclude over $36 \%$ of the world's population (as of 2014 ) and two of the fastest-growing 


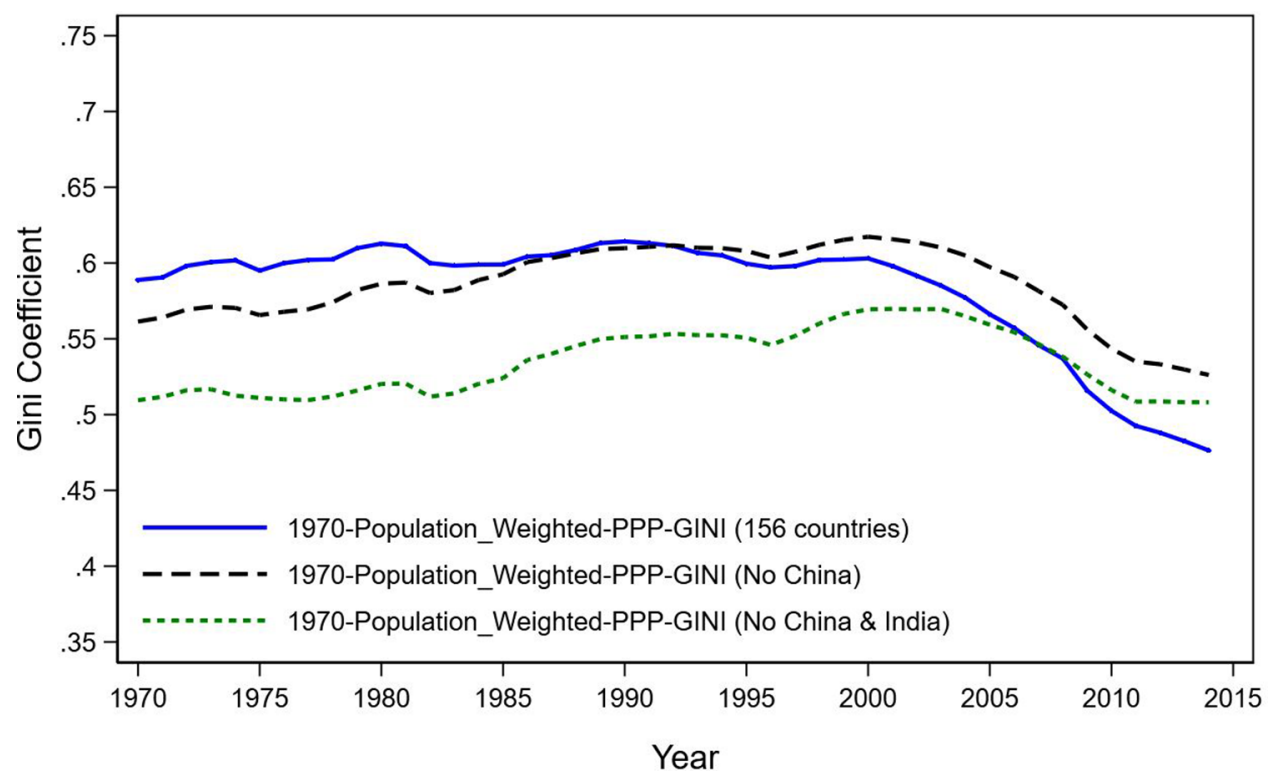

FIGURE 7. The "Chindia Effect": Trend in Population-Weighted Between-Country Inequality without China and without China and India

large economies from the calculation of inequality, population-weighted between-country still measurably declined in recent years.

\section{The Gap between the Rich and the Rest}

Our examination of weighted between-country inequality reveals a real reduction in inequality after 2000. Much of the literature on global inequality and development has, at least implicitly, been concerned with convergence/divergence between the "Rich" and the "Rest" (Amsden 2001; Arrighi, Silver, and Brewer 2003; Firebaugh and Goesling 2004). As our results imply convergence in average real incomes in recent decades, we explicitly illustrate this, comparing historically rich advanced economies to other countries in the 1970 sample.

Figure 8 displays the trends in average PPP-adjusted GDP per capita from the PWT. These average real income trends are weighted by each group's/country's population size such that, for instance, China has a larger weight in the computation of the average income series for the Rest group than does Sri Lanka. The Rich country sample consists of all countries in Western Europe, the U.S., Canada, New Zealand, Australia, and Japan. Figure 8 also displays the trend in average real income for China and India alone. Figure 9 presents two series based on the information in Figure 8: the difference in average real income between rich and other countries, and the ratio between the two.

A few facts stand out. The series for the Rich in Figure 8 is visibly responsive to the business cycle, showing declines in response to the global recessions of the mid-1970s, the early I980s, and 2008. Otherwise, average real income rises continuously from 1970 to 2014 . In contrast, the series for the Rest in Figure 8 is comparatively flat across the 1970s, I980s, and into the I990s, after which average incomes begin to tick up, undoubtedly helped along by China, which moves from having below-average income for the Rest to above-average by the 


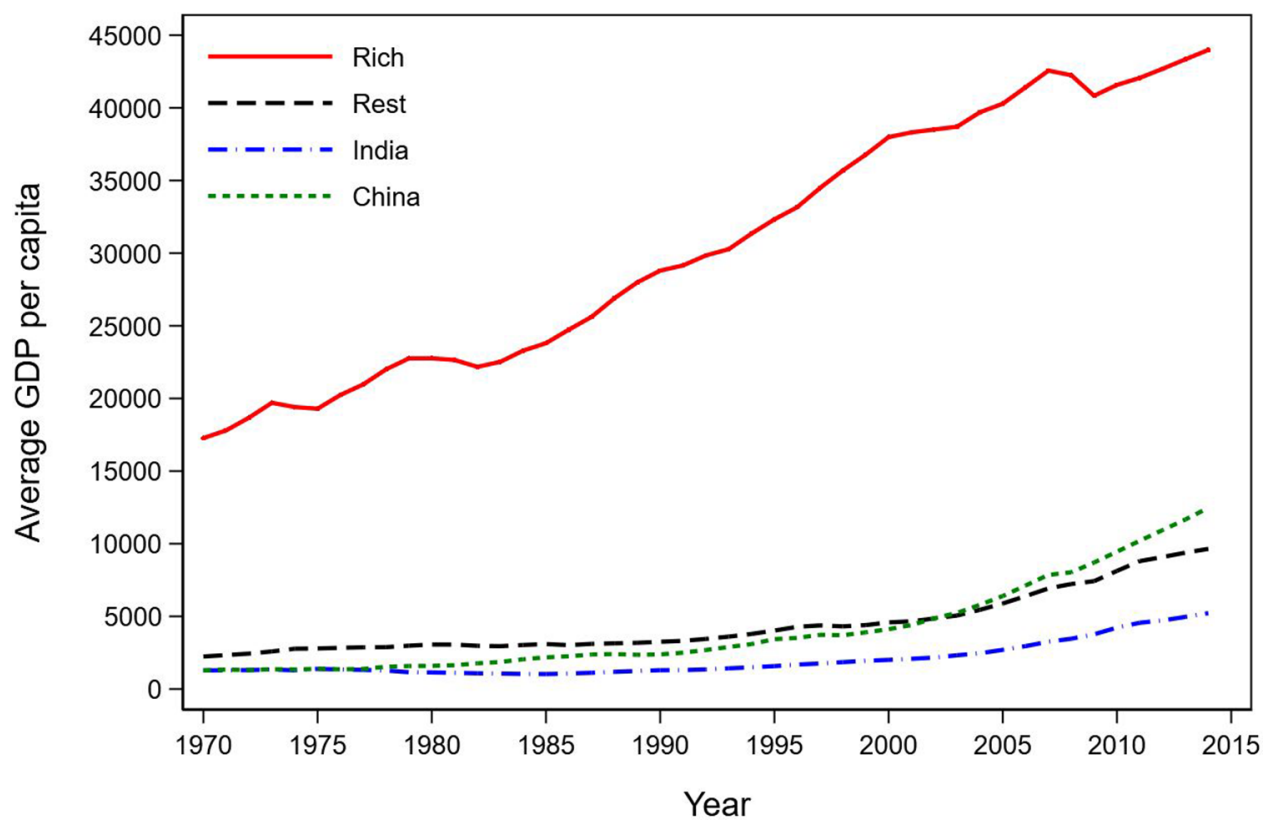

FIGURE 8. Trend in Average Real Income: The Rich, the Rest, China, and India

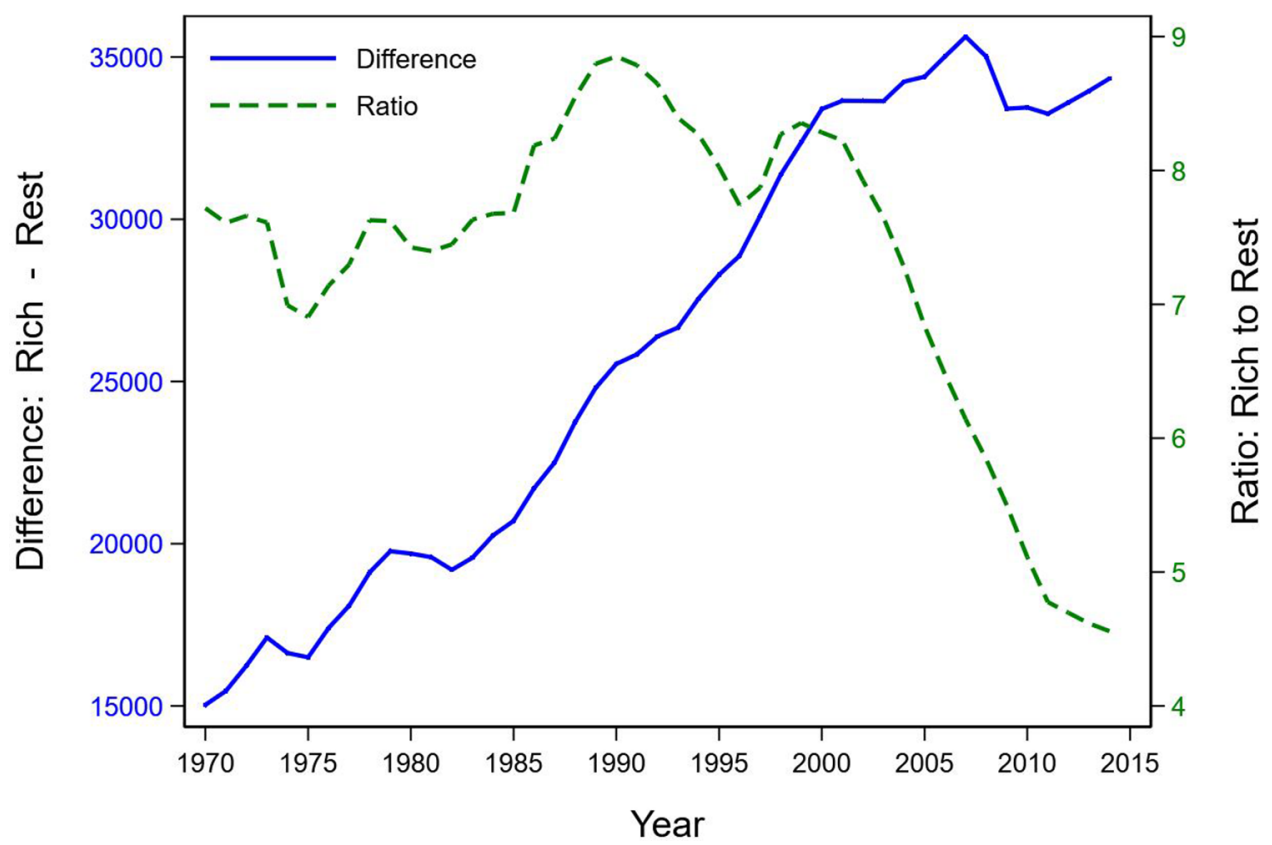

FIGURE 9. Trend in the Difference in Average Real Income between the Rich and the Rest and the Ratio of the Income of the Rich to the Rest 
early 2000s. Turning to Figure 9, the difference in average real income between the Rich and the Rest increased from just over $\$ 15,000$ in 1970 to more than $\$ 33,000$ in 2014 (2011 USD), following a decline and partial recovery after 2008. However, the income of the Rich relative to the Rest fell precipitously after 2000, from being 8.3 times larger in 2000 to 4.6 times larger in 2014 . Given that average real income in both groups was higher in 2014 than in 2000 , this is clear evidence that the Rest have been growing faster than the Rich for all of the present century. Thus, in addition to representing a significant break in inequality, the post-2000 era represents a critical shift in the divergence/convergence dynamics between historically rich and other countries.

\section{"TRUE" GLOBAL INEQUALITY}

Over simple international inequality (i.e., unweighted between-country inequality), weighted between-country inequality represents a significant step toward an ideal measure of global inequality (i.e., one based on information on every income-receiving unit-individual, household, or family-in the world). Instead of treating, for instance, China as equivalent to the Seychelles, population-weighting gives China more than I4,500 times the influence of the Seychelles in the calculation of between-country inequality. It is, nevertheless, inherently limited as a measure of global inequality. In weighting GDP per capita by population, one, in effect, gives all members of the society the same income. All 96,000 people in the Seychelles are given the same income, the income per capita of the Seychelles, and all I. 4 billion Chinese are given the same income, the income per capita of China. That is, weighted between-country inequality is a crude approximation of true global inequality, as it assumes there is no inequality of income within countries. Therefore, what the results presented in Figure 3 in fact represent is a measure of the lower bound of global inequality in each year. They represent the lower bound because we know, of course, that there is inequality to varying degrees within each society. Looking back to Figure 3, what this tells us, for example, is that global inequality in 2014 could not possibly have been any lower than around 0.45 or 45 Gini points. We know it could not be any lower than that, but we really don't know how much higher it might be-or how much higher global inequality would be if we factored in within-country inequality, which, as we saw, has been growing in the typical society in recent decades.

The fact that population-weighted between-country inequality represents a lower bound raises the question of what the upper bound of global inequality might be. As Milanovic (2013b) has shown, it is easy to calculate this. One can estimate the upper bound or ceiling of global inequality in a given year by relating subsistence income to average income. That is, assume a world in which all but a minuscule elite live on the World Bank's international poverty line of $\$$ I.90 a day, or $\$ 693.50$ a year (201 I USD). One can use per capita income data to calculate the Gini coefficient of inequality under those conditions as:

$$
\text { Maximum Gini }=\alpha-1 / \alpha
$$

where $\alpha$ is the ratio between mean and subsistence income. By this formula one can see that if mean income is low, the maximum possible Gini will be low, because the surplus 
available to the elite is small. As average income grows, however, the maximum possible Gini will approach 1.0 as the surplus that could be captured by the elite grows.

Estimates of the upper bound of global inequality are presented in Figure io using the 1960 series. In this figure, we also reproduce the 1960 and 1970 series of weighted between-country inequality. By this measure, a maximally unequal world of 1960 could have had a Gini coefficient no higher than about 0.83 . As average real incomes have grown, potential global inequality has likewise grown, and, by 2014, a maximally unequal world in which nearly everybody lived on \$I.9O a day could have had a Gini coefficient no higher than 0.95 . Tracing out this theoretical maximum is helpful as it provides some bounds for our estimates of "true" global inequality. We know that global inequality can be no higher than what we see in Figure Io. Likewise, we know that global inequality can be no lower than the bounds traced out by weighted between-country inequality. Thus an estimate of global inequality of, say, 0.82 in 2014 simply lacks face validity; it is too close to what we would see in a maximally unequal world. Similarly, an estimate of 0.47 in 2014 is simply too low; it is too close to what we would see in a world in which the only source of income inequality is differences in average income between countries. The true value must lie somewhere between these extremes.

Milanovic's work gets us as close as we have come to date to the ideal of having information on every income-receiving unit in the world. Milanovic's estimates of global inequality are based on household income surveys that are generalizable to over $80 \%$ of the world's population in all years. ${ }^{8}$ The data we present in Figure 10 are drawn from Milanovic and Roemer (2016). They use the same 20I PPPs that we have used throughout, allowing

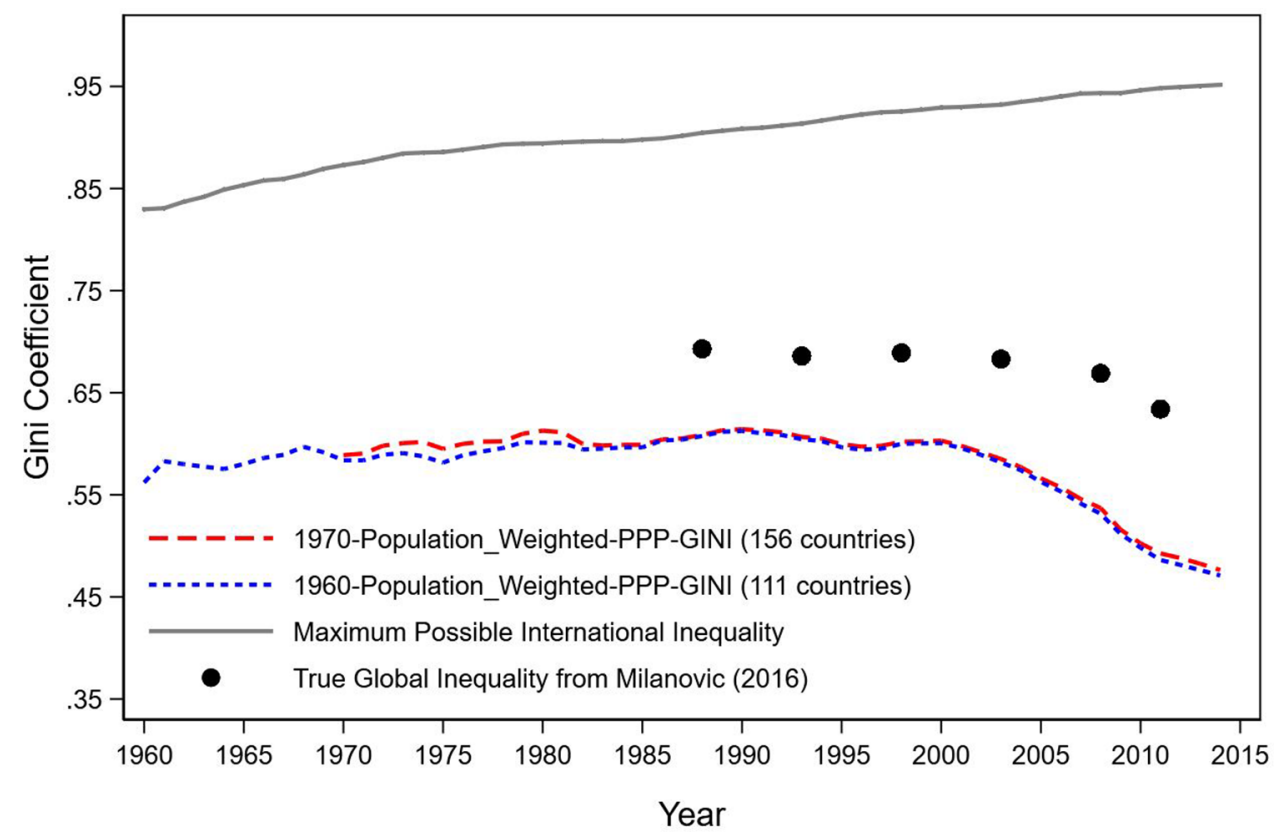

FIGURE 10. Estimates of True Global Inequality and the Trends in Maximum Possible Inequality and Weighted Between-Country Inequality 
an "apples to apples" comparison of their estimates to our upper and lower bounds of global inequality. Estimates of true global inequality roughly mirror the trajectory of weighted between-country inequality, being more or less stable across the late I980s and I990s, but turning to decline thereafter. The decline in global inequality between 1998 and $201 \mathrm{I}$ is substantively meaningful, 5.5 Gini points. In terms of the two-person cake-sharing game described above, the decline of 5.5 Gini points is equivalent to the person receiving the smaller slice in 1998 receiving $2.75 \%$ more cake by 201 . Given the slow pace at which income inequality typically changes-"like watching the grass grow," as Aaron (1978) famously quipped-this is a remarkable shift for 13 years (especially when one recalls that the changes underlying this shift have moved tens of millions out of absolute poverty). It is also interesting to note the growing divergence between our best estimates of true global inequality and the trend in maximum possible inequality in Figure Io. As the world has gotten richer, the amount of inequality that could be produced or extracted in the world system has grown, but the proportion produced (i.e., true global inequality/maximum possible inequality) is declining, and notably so after 2000. Thus, even though inequality has been growing within the typical society, we have moved meaningfully further away from a world in which all but a tiny minority live on the edge of subsistence.

\section{CONCLUSIONS}

To recapitulate, using the latest available data on within- and between-country inequality, we find that inequality within countries has been on the rise and argue that there is little reason to expect in the near term that further economic development will result in a reduction in inequality within the typical society, whether developed or developing. Inequality between countries continued to grow for much of the latter half of the $20^{\text {th }}$ century, as it had for the last few centuries, but turned to decline measurably after 2000 . We have demonstrated that this decline is robust to the methodological and measurement issues raised in the literature and argued that it is primarily attributable to the now familiar improvement in average incomes in a number of developing societies. Tracing out the lower and upper bounds of global inequality, we then situated estimates of true global inequality within them. The data available on true global inequality suggest stability, then a substantively meaningful decline, again, around the turn of the century.

Having detailed what is really happening with global inequality, we conclude with a number of thoughts on what we think it really means looking forward. First, in a postindustrial-transition world-one in which further economic development cannot be expected to result in reductions in inequality within societies-most of the "action" on the inequalityreduction front is likely to be "global." That is, if we are going to see further reduction in global inequality in the near term, it is probably going to be the result of continued international trade, investment, and migration producing rising average incomes in developing societies, rather than the moderation of inequality within countries. Second, it is clear, in practice, despite much discussion to the contrary, policy makers have largely overlooked the stakes involved for their constituents. As we noted earlier, what country you live in remains, by a large margin, the single biggest determinant of your income. This is of 
course, a pure accident of birth for the vast majority. As Milanovic (2015) has shown, on a global level there is precious little "equality of opportunity:" those who live in rich countries enjoy massive rents on citizenship, rents that very few are prepared to forgo. Third, it is plainly not obvious to all that globalization has always represented a Pareto improvement; that is, it is not obvious to all that global trade and investment have made hundreds of millions people in developing societies better off without making other people-the middle and working classes of the rich countries-worse off. It is thus not at all surprising that the factors underlying the trends we document in this paper have spawned a political constituency in both the Global North and South that is strongly opposed to globalization. Members of that constituency feel that they have a lot to lose-and many certainly do-and they feel as if they have been losing. To our minds, further reductions in global inequality that rely on the primary mechanism (i.e., globalization) through which this has occurred in recent decades may turn critically on the ability of policymakers to devise ways of ensuring that globalization is more broadly experienced and viewed as welfare enhancing. As happened with the last great round of globalization in the late nineteenth and early twentieth centuries (Chase-Dunn, Kawano, and Brewer 2000), the window can close as just as quickly as it opened.

That said, the role of globalization in current and future inequality reduction is multifaceted and must be approached critically. For instance, while the latest data indicate a substantial decline in between-country and global inequality after 2000 , it is important to note that this is well after the onset of the most recent round of globalization (as conventionally dated) and later than earlier studies had indicated. This may reflect the fact that the pathways through which globalization shapes the growth trajectories of nations varies. While the role of export-led industrialization in China's growth is clear, manufactured exports have played a relatively minor role in India's growth story in the past decade. India's growth has been driven more by domestic consumption fueled by foreign capital inflows (Ghosh and Chandrasekhar 2009; Hung 2015). The experiences of individual nations suggest that the case for simply increasing trade and foreign investment (especially short-term capital flows) is not always unambiguously positive. To be sure, globalization has been important in the export-led take-off of China and, before then, the East Asian Tigers like South Korea and Taiwan. In contrast to the earlier success stories of East Asian countries, China has had a particularly large impact on reducing global inequality because of its size. However, it is also important to remember that these countries did not embrace trade liberalization blindly. As the large literature on developmental states reveals, late industrializers engaged in a more selective integration with the world economy (Amsden 200I; Johnson 1982; Chang 2006; Hung 2015). Furthermore, financial liberalization that encourages short-term capital flows and speculation can lead to instability and crises, like the East Asian financial crisis in the late I990s. And the competitive shock associated with the entry of Asian countries like China into export markets can "close out" other developing countries (Kaplinsky 2005; Rodrik 2016). In sum, the process of globalization that has played an important role in the rapid growth of some developing countries has not engendered the same in other developing countries, nor can it be assumed that it will do so in the future. 


\section{WORKS CITED}

Aaron, Hentry. 1978. Politics and the Professors: The Great Society in Perspective. Washington D.C.: Brookings Institution.

Ahluwalia, Montek S. 1976. "Income Distribution and Development: Some Stylized Facts." American Economic Review 66:128-35.

Alderson, Arthur S., and François Nielsen. 2002. "Globalization and the Great U-Turn: Income Inequality Trends in 16 OECD Countries." American Journal of Sociology 107:1244-1299.

Amsden, Alice H. 2001. The Rise of "the Rest": Challenges to the West from Late-Industrializing Economies. Oxford: Oxford University Press.

Anand, Sudhir, and Paul Segal. 2008. "What Do We Know about Global Income Inequality?” Journal of Economic Literature 46:57-94.

Arrighi, Giovanni, Beverly Silver, and Benjamin Brewer. 2003. "Industrial Convergence, Globalization, and the Persistence of the North-South Divide." Studies in Comparative International Development 38:3-31.

Babones, Salvatore. 2002. "Population and Sample Effects in Measuring International Income Inequality." Journal of World-Systems Research 8:8-28.

Babones, Salvatore. 2005. "The Country-Level Income Structure of the World-Economy." Journal of World-Systems Research 11:29-55.

Barro, Robert. 2008. "Inequality and Growth Revisited." Working Paper Series on Regional Economic Integration 11:1-14. Manila, Philippines: Asian Development Bank.

Bluestone Barry. 1990. "The Great U-Turn Revisited: Economic Restructuring, Jobs, and the Redistribution of Earnings." Pp. 7-43 in Jobs, Earnings, and Employment Growth Policies in the United States, edited by John D. Kasarda. Boston, MA: Kluwer.

Bourguignon, François, and Christian Morrisson. 2002. "Inequality among World Citizens: 18201992." American Economic Review 92:727-44.

Brady, David, Yunus Kaya, and Gary Gereffi. 2011. "Stagnating Industrial Employment in Latin America." Work \& Occupations 38(2):179-220.

Chase-Dunn, Christopher, Yukio Kawano, and Benjamin D. Brewer. 2000. "Trade Globalization since 1795: Waves of Integration in the World-System." American Sociological Review 65:77-95.

Chang, Ha-Joon. 2006. The East Asian Development Experience: the Miracle, the Crisis and the Future. London: Zed Books.

Clark, Rob. 2011. "World Income Inequality in the Global Era." Social Problems 58(4):565-592.

Clark, Rob. 2016. "Examining Mobility in International Development." Social Problems 63(3):329-350.

Coady, David, and Allan Dizioli. 2017. "Income Inequality and Education Revisited: Persistence, Endogeneity, and Heterogeneity." Working Paper No. 17/126. Washington, DC: International Monetary Fund.

Cornia, Giovanni Andrea, Tony Addison, and Sampsa Kiiski. 2003. "Income Distribution Changes and their Impact in the Post-World War II Period.” UNU/WIDER Discussion Paper No. 2003/28. Helsinki, Finland.

Deininger, Klaus, and Lyn Squire. 1998. "New Ways of Looking at Old Issues: Inequality and Growth." Journal of Development Economics 57:259-87.

Dowrick, Steve, and Muhammad Akmal. 2005. "Contradictory Trends in Global Income Inequality: A Tale of Two Biases." Review of Income and Wealth 51:201-229.

Feenstra, Robert C., Robert Inklaar and Marcel P. Timmer. 2015. "The Next Generation of the Penn World Table." American Economic Review 105(10):3150-3182, available for download at www. ggdc.net/pwt.

Fields, Gary S. 2001. Distribution and Development: A New Look at the Developing World. New York: Russell Sage Foundation.

Firebaugh, Glenn. 1999. "Empirics of World Income Inequality." American Journal of Sociology 104:1597-1630. 
Firebaugh, Glenn. 2003. The New Geography of Global Income Inequality. Cambridge, MA: Harvard University Press.

Firebaugh, Glenn, and Brian Goesling. 2004. "Accounting for the Recent Decline in Global Income Inequality.” American Journal of Sociology 110:283-312.

Galbraith, James K. 2011. "Inequality and Economic and Political Change: A Comparative Persepective." Cambridge Journal of Regions, Economy and Society 4:13-27.

Goesling, Brian. 2001. "Changing Income Inequalities within and between Nations: New Evidence." American Sociological Review 66:745-61.

Ghosh, Jayati, and C. P. Chandrasekhar. 2009. "The Costs of Coupling: The Global Crisis and the Indian Economy.” Cambridge Journal of Economics 33:725-739.

Harrison, Bennett, and Barry Bluestone. 1988. The Great U-Turn. New York: Basic Books.

Hung, Ho-Fung, and Jaime Kucinskas. 2011. "Globalization and Global Inequality: Assessing the Impact of the Rise of China and India, 1980-2005." American Journal of Sociology 116:1478-1513.

Hung, Ho-Fung. 2015. The China Boom: Why China Will Not Rule the World. New York: Columbia University Press.

International Labour Organization. 2018. ILOSTAT database. Retrieved February 21, 2018.

Johnson, Chalmers. 1982. MITI and the Japanese Miracle: the Growth of Industrial Policy: 1925-1975. Stanford, CA: Stanford University Press.

Kaplinsky, Raphael. 2005. Globalization, Poverty and Inequality: Between a Rock and a Hard Place. Malden, MA: Polity.

Korzeniewicz, Roberto P., and Timothy P. Moran. 1997. "World-Economic Trends in the Distribution of Income, 1965-1992." American Journal of Sociology 102:1000-39.

Korzeniewicz, Roberto P., and Timothy P. Moran. 2000. "Measuring World Income Inequalities." American Journal of Sociology 106:209-14.

Kuznets, Simon. 1955. "Economic Growth and Income Inequality." American Economic Review 45:1-28.

Levy, Frank, and Richard J. Murname. 1992. "U.S. Earnings Levels and Earnings Inequality: A Review of Recent Trends and Proposed Explanations." Journal of Economic Literature 30:1333-81.

Melchior, Arne, and Kjetil Telle. 2001. "Global Income Distribution 1965-98: Convergence and Marginalisation.” Forum for Development Studies 1:75-98.

Milanovic, Branko. 2011. "Global Inequality and the Global Inequality Extraction Ratio: The Story of the Past Two Centuries." Explorations in Economic History 48:494-506.

Milanovic, Branko. 2013a. "Global Income Inequality in Numbers: in History and Now." Global Policy 4:198-208.

Milanovic, Branko. 2013b. "The Inequality Possibility Frontier: Extensions and New Applications." World Bank Policy Research Working Paper 6449. Washington, DC: World Bank.

Milanovic, Branko. 2015. "Global Inequality of Opportunity: How Much of Our Income Is Determined by Where We Live?" Review of Economics and Statistics 97:452-460.

Milanovic, Branko. 2016a. Global Inequality: A New Approach for the Age of Globalization. Harvard University Press, Cambridge, MA.

Milanovic, Branko. 2016b. "Recent Trends in Global Income Inequality and Their Political Implications." Presented at Università Bocconi, November 21, Milan, Italy. Retrieved October 21, 2017. (https://www.unibocconi.eu/wps/wcm/connect/c041eee5-b5da-4fc5-8a7d-97f874d5cc22/Milanovic_ Recent+trends+in+global+income+inequality.pdf?MOD=AJPERES)

Milanovic, Branko, and John E. Roemer 2016. "Interaction of Global and National Income Inequalities" Journal of Globalization and Development 7:109-115.

Moller, Stephanie, Arthur S. Alderson and François Nielsen. 2009. "Changing Patterns of Income Inequality in U.S. Counties, 1970-2000.” American Journal of Sociology 114:1037-1101.

Nielsen, François. 1994. "Income Inequality and Industrial Development: Dualism Revisited." American Sociological Review 59:654-77. 
Nielsen, François, and Arthur S. Alderson. 1995. "Income Inequality, Development, and Dualism: Results from an Unbalanced Cross-National Panel.” American Sociological Review 60:674-701.

Peacock, Walter, Greg Hoover, and Charles Killian. 1988. "Divergence and Convergence in International Development: A Decomposition Analysis of Inequality in the World System." American Sociological Review 53:838-52.

Pomeranz, Kenneth. 2001. The Great Divergence: China, Europe, and the Making of the Modern World Economy. Princeton, NJ: Princeton University Press.

Rodrik, Dani. 2016. "Premature Deindustrialization." Journal of Economic Growth 21:1-33.

Sala-i-Martin, Xavier. 2002. "The Disturbing 'Rise' of Global Income Inequality.” NBER Working Paper no. 8904. Cambridge, MA.

Schultz, T. Paul. 1998. "Inequality in the Distribution of Personal Income in the World: How It Is Changing and Why." Journal of Population Economics 11:307-44.

Subramanian, S. 2002. "An Elementary Interpretation of the Gini Inequality Index." Theory and Decision 52:375-379.

Singelmann, Joachim, Forrest A. Deseran, F. Carson Mencken, and Jiang Hong Li. 1993. "What Drives Labor Market Growth: Economic Performance of Labor Market Areas: 1980-86.” Pp. 33-49 in Inequalities in Labor Market Areas, edited by Joachim Singlemann and Forrest A. Deseran. Boulder, Colo.: Westview Press.

UNU-WIDER. 2017. "World Income Inequality Database (WIID3.4)," January 2017.

Wade, Robert H. 2004. "Is Globalization Reducing Poverty and Inequality?" World Development 32:567-589.

Wallerstein, Immanuel M. 2004. World-Systems Analysis: An Introduction. Durham, NC: Duke University Press.

World Bank. 2008. Global Purchasing Power Parities and Real Expenditures - 2005 International Comparison Program. Washington, DC: World Bank.

World Bank. 2017. "World Development Indicators" Washington, DC. World Bank. Retrieved January 6, 2017 (https://data.worldbank.org/indicator/SP.POP.TOTL)

\section{NOTES}

Direct all correspondence to Arthur S. Alderson, Department of Sociology, Indiana University, Ballantine Hall 744, Bloomington, IN 47405. Email for Alderson: aralders@indiana.edu. Email for Pandian: rpandian@indiana.edu.

I. This would be an ideal situation for the study of global inequality. Barring such a global census, it would be ideal to have regular, high-quality income surveys of all countries in the world. Neither, to date, exist; in a real sense, the various estimates of global inequality that we produce and discuss below retrace the history of the (always limited, but increasingly successful)attempts of social scientists to approximate this ideal.

2. The Gini coefficient is a measure of inequality that varies between $\circ$ and $\mathrm{I}$, with $\circ$ representing perfect equality (i.e., all income-receiving units receive the same income) and I representing perfect inequality (i.e., one income-receiving unit receives all of the income). Thus a change of "s Gini points" represents a change in the Gini of 0.05 (or, when multiplied by 100 as in Figures I and 2 below, a change of 5 ).

3. See Nielsen (1994) for an illustration and Nielsen and Alderson (1995) for an application.

4. Data in the WIID are of widely varying quality and there are a host of measurement issues that one must address to treat the data as comparable. Given that Figures I and 2 are intended only to illustrate a few key points over which there is very little doubt, we forgo the usual rules of good practice and simply present all of the data for the 1960s and 20Ios in the latest release of the WIID.

5. This is not to suggest that the general mechanism identified by Kuznets cannot help us make sense of rising inequality. For instance, in the course of the spread of education, one would expect inequality 
to rise, then fall, given that the heterogenity of educational attainment will likewise increase, then decrease, as the population shifts from low to high levels of formal schooling (Moller, Alderson, and Nielsen 2008; Coady and Dizioli 2017). See also Milanovic (2016a) on "Kuznets cycles."

6. For a more detailed description of the updates to PPP construction and other updates to PWT, see Feenstra, Inklaar, and Timmer (2015) or the PWT user guides.

7. For a full description of the differences between the PWT and World Bank PPP-adjusted GDP per capita figures, refer to Feenstra, Inklaar and Timmer (2013) and World Bank (2008).

8. See Milanovic 2016a for details. The surveys employed allow one to draw inferences to between $8 \mathrm{r} \%$ (1988) and $94 \%$ (2003) of world population. 


\title{
What is Really Happening with Global Inequality?
}

\begin{abstract}
We use the latest available data from the World Income Inequality Database 3.4 and the Penn World Tables 9.0 to examine some of the core issues and concerns that have animated research on global inequality. We begin by reviewing the evidence on trends in within-country inequality, drawing out some of the implications of this for our thinking about inequality and economic development. We examine betweencountry inequality, computing updated estimates of trends in both unweighted and population-weighted between-country inequality. The data reveal that inequality between countries increased across the latter half of the twentieth century, then turned to decline measurably thereafter. We show that this decline is robust to a range of methodological and measurement decisions identified as important in previous research. We then examine estimates of true global inequality, situating these in relation to lower- and upper-bound estimates of global inequality. We conclude by noting the critical and contested role of globalization in inequality reduction. KEYWORDS global inequality, within-country inequality, between-country inequality
\end{abstract}

A few centuries ago the global distribution of income looked quite different than it does today. By current standards and metrics, the world was poor, and most of the inequality in the world distribution of income was attributable to within-nation income differences. That is, imagine that we had income data on every individual or household in the world. ${ }^{1}$ With that, one could calculate some measure of global income inequality. If we took that measure and decomposed it into its within- and between-country components, we would find that the within component was much larger than the between component. As Milanovic (2013a) has put it, it was a world in which "class" mattered far more than "location" (i.e, the country in which one lived) for one's position in the global distribution of income. Indeed, as recently as the first half of the nineteenth century, our best estimates suggest that something on the order of $80 \%$ of global inequality was within country, and only about $20 \%$ was between (Bourguinon and Morrisson 2002). Simply put, the gap between rich and poor within countries made a much larger contribution to global inequality than the gap between rich and poor countries.

Over the next two centuries, this changed dramatically and fundamentally. The Industrial Revolution and the sustained economic growth that characterized Western nations in the nineteenth century led to a "Great Divergence" between the West and the rest of the world (Pomeranz 200I). In that process, income differences between societies ballooned to dominate the world distribution of income (Milanovic 2011, 2016a). Presently, betweencountry income inequality accounts for around two-thirds of total global inequality. In other words, if we eliminated inequality within countries entirely-if we took the income

Sociology of Development, Vol. 4, Number 3, pps. 26I-28I. electronic ISSN 2374-538X. (c) 2018 by the Regents of the University of California. All rights reserved. Please direct all requests for permission to photocopy or reproduce article content through the University of California Press's Reprints and Permissions web page, www.ucpress.edu/journals. php?p=reprints. DOI: https://doi.org/I0.1525/sod.2018.4.3.26I. 
generated in each society and divided it equally among the members of that society, and did that for every society around the world-global inequality today would decline only by about a third. Moreover, over half of the variation in personal incomes globally is accounted for simply by the average national income of one's country of residence (Milanovic 2013a). The combined explanatory power of a collection of personal characteristics that are well known to be associated with one's income-social class, gender, race, education, family background, and so on-pale in comparison to that of a single variable today: the country in which you live.

Over the past two decades, research in sociology and economics has generated considerable debate over the empirics of global inequality and the factors underlying these trends (e.g., Korzeniewicz and Moran 1997; Firebaugh 2003; Firebaugh and Goesling 2004; Anand and Segal 2008; Dowrick and Akmal 2005). While there is a scholarly consensus that global income inequality had been rising for most of the twentieth century, the trajectory of global inequality in the last decades of the twentieth century has been a subject of debate. Given an emerging consensus that the last decades of the past century saw an increase in income inequality within the typical society (Cornia, Addison, and Kiiski 2003; Firebaugh 2003; Goesling 200I), much of the debate about contemporary inequality trends centers on the between-country component. Some have found that global inequality declined in the last two decades of the twentieth century (e.g., Firebaugh 1999, 2003; Goesling 2001; Melchior and Telle 2001; Sala-i-Martin 2002), while others have argued that such findings are sensitive to methodological decisions, such as the use of purchasing power parity (PPP) versus market exchange rates, how PPP is constructed (i.e., the Geary-Khamis vs. Eltetö-Köves-Szulc methods), the use of population weights, and the inclusion of China (Anand and Segal 2008; Arrighi, Silver, and Brewer 2003; Wade 2004; Clark 2011; Dowrick and Akmal 2005; Firebaugh 2003; Hung and Kucinskas 2011; Melchior and Telle 2001).

In this article, we revisit this debate, using the latest available data and ask: What is really happening with global inequality? We proceed in three steps. First, we briefly review the evidence on trends in within-country inequality, noting that, on a global scale, the transition of employment out of agriculture into industry and services is rapidly nearing completion and drawing out some of the implications of this for our understanding of global inequality. Second, we examine between-country inequality, computing updated estimates of trends in unweighted and population-weighted between-country inequality using data from the Penn World Tables (PWT) 9.0 (Feenstra, Inklaar, and Timmer 2015). These data reveal that inequality between countries increased across the latter half of the twentieth century, then turned to decline measurably thereafter. We show that this decline is robust to a range of methodological and measurement decisions identified as important in previous research. Finally, we examine extant estimates of "true" global inequality, situating these in relation to theoretical lower- and upper-bound estimates that we derive from the latest data.

\section{WITHIN-COUNTRY INCOME INEQUALITY}

Studies of within-country income inequality have generally found that inequality has increased in most societies since the I970s. For example, using data from the World Income 
Inequality Database (WIID) and focusing on the subset of societies for which we have the most reliable data, Cornia, Addison, and Kiiski (2003) find that income inequality increased in about two-thirds of the world's societies. Inequality grew in developed and many developing countries, and in nearly all post-communist societies. Similarly, using the University of Texas Inequality Project Data on pay inequality, Galbraith (20II) finds that inequality increased in the typical country and increased more steeply in developing societies than in developed ones. Finally, using the "AlltheGinis" data set, Milanovic (2016b) likewise reports that income inequality grew in about two-thirds of the countries under examination since the late I980s. Both Cornia, Addison, and Kiiski (2003) and Milanovic (2016b) find that the inequality upswing was typically substantively meaningful, at 5 Gini points or greater in most of the countries experiencing rising inequality. ${ }^{2}$ What does an increase in income inequality of 5 Gini points mean? Expressed in terms of a cake-sharing game in which two people divide a cake between them, if Person A received the smaller slice at Time I, a rise of 5 Gini points means that Person A would receive $2.5 \%$ less cake at Time 2 (Subramanian 2002).

This upswing in inequality occurring across countries at various levels of development has raised new questions about the relationship between inequality and long-run economic development. For some time, social scientific thinking on this had been dominated by the familiar image of the Kuznets Curve (Kuznets 1955), the central insight being that industrialization is associated with a variety of compositional changes that generate an inverted-U-shaped relationship between inequality and development. "Starting" from a low level of development in which the low productivity/income agrarian sector dominates, the shift of the labor force in the course of industrialization into the higher productivity/income manufacturing and service sectors produces, mechanically, rising then falling inequality over the course of the industrial transition. ${ }^{3}$ The implications of this classic account for contemporary developing and developed societies has been a subject of regular and recurring debate. Some find support for an inverted$\mathrm{U}$ relationship between economic development and income inequality (e.g., Ahluwalia 1976; Nielsen and Alderson 1995; Barro 2008), while others argue that there is scant evidence, longitudinally, that present-day developing societies conform to the Kuznetsian pattern and that Kuznets's argument is, in any case, poorly equipped to explain the increase in inequality that many developed societies have experienced since the i970s (e.g., Alderson and Nielsen 2002; Fields 2001; Deininger and Squire 1998; Harrison and Bluestone 1988; Bluestone 1990).

What should we infer from this debate, and how should we think about the relationship between inequality and development today? Viewed globally, we think it critical to note that the industrial transition-the shift out of agriculture and into industry and services, which Kuznets saw as the central mechanism lying behind the Kuznets Curve-is drawing to a close. Sometime in the 1980 -for the first time in thousands of years-more people in the world worked outside the agricultural sector than within it. Data on employment by sector collected by the International Labor Organization (2018) reveals that, by 200I, agriculture was no longer even the modal sector of employment globally. In that year, employment in services surpassed that in agriculture. This indicates that, at a global level, we are presently 
beyond the point at which the dualism between the agriculture and non-agricultural sectors would be expected to drive inequality upward in the typical developing society.

A quick look at the data on within-country inequality bears this out. In the left panel of Figure I, we pool all of the data that we have on income inequality for the 1960 s from version 3.4 of the WIID (UNU-WIDER 2017) and plot this against a measure of real GDP/ Capita (20II USD) from version 9.0 of the PWT (Feenstra, Inklaar, and Timmer 2015). In the right panel, we do the same for the present decade. As one can note, in the 1960s, the familiar inverted $U$ of the Kuznets Curve emerges in these data. Doing the same for every decade (not shown), one can observe that, by the 20 Ios, the world's societies have shifted notably to the right (i.e., average income increases) and most societies have moved well into the industrial transition (i.e., to the right of the inflection point of the Kuznets Curve). In Figure 2, we show how the level of inequality has changed over the past six decades. Consistent with the literature on within-country inequality, we see that inequality, on average, declined across the 1960 s, the I970s, and into the 1980 s, after which it turned to increase. While the reader should not put too fine a point on this, the increase that we see between the 1980 s and 20ros-an increase at the median of about 4.5 Gini points-is of roughly the same order as that reported by Cornia, Addison, and Kiiski (2003) and Milanovic (2016b), based on a far more careful approach to the data. ${ }^{4}$

Presently, then, we live in a world in which richer societies tend to have lower levels of inequality than poorer societies, but also one in which many societies, rich and poor alike, are on a trajectory of rising inequality. Just as there is nothing in Kuznets's original argument that would lead us to anticipate the U-turn on inequality that began in many rich societies in the 1970s, it is not obvious, within this framework, how one might reconcile the increase in inequality in many developing societies with the fact that they are already well into the industrial transition; that is, beyond the point at which dualism between agriculture and non-agricultural sectors would be expected to drive inequality upward in the typical developing society. ${ }^{5}$ Interestingly, the post-industrial-transition distribution of the labor force across sectors in these societies appears to have been evolving rather differently than it did in
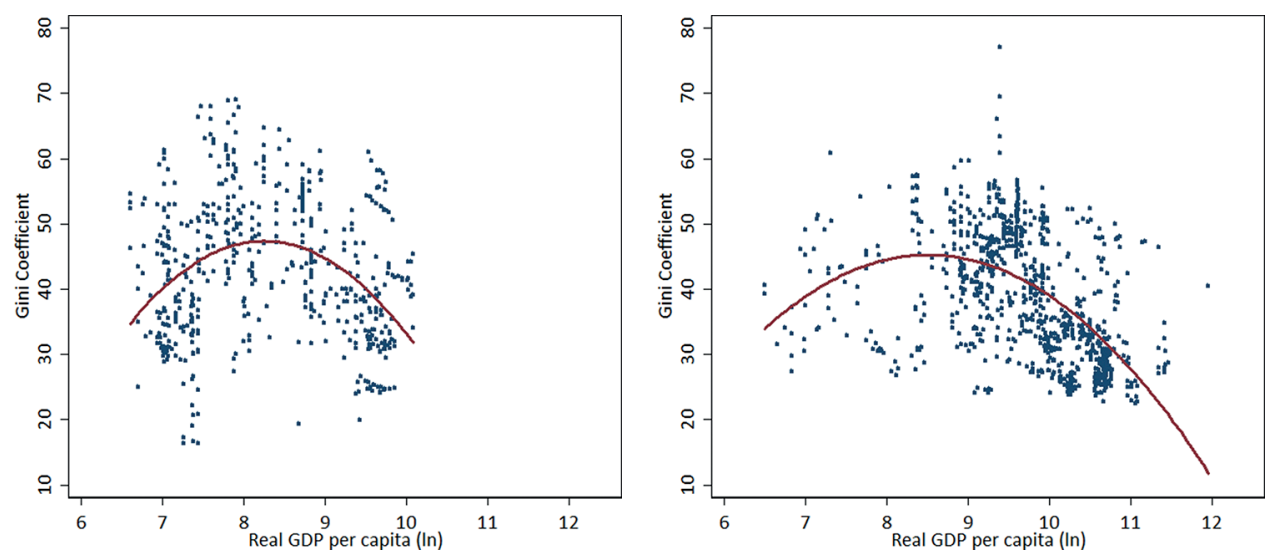

FIGURE 1. Inequality and Development in the World Income Inequality Database 3.4, All Observations Available for the r 960 s and the 2010 s 


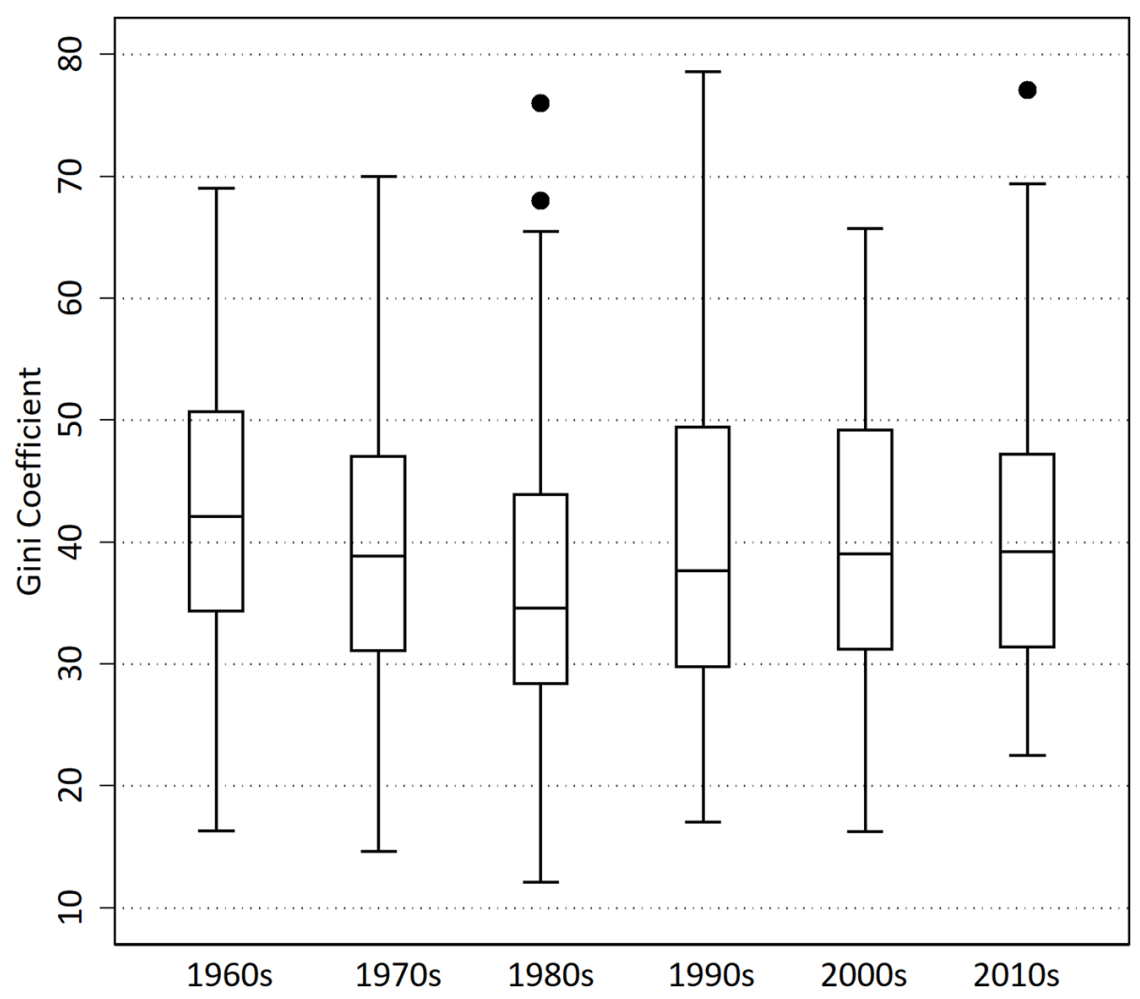

FIGURE 2. All of the Data from the World Income Inequality Database $3.4(\mathrm{~N}=7447$, 1960-2014)

the rich societies. Scholars have recently begun to document deindustrialization in developing nations, particularly in Latin America and Sub-Saharan Africa (Brady, Kaya, and Gereffi 20II; Rodrik 2016). This process of declining manufacturing employment, termed "premature deindustrialization," is striking because it has begun at a lower level of economic development than it did in rich societies, a phenomenon that Rodrik (2016) explains in terms of heightened global competition. The combination of declining primary- and secondary-sector employment in developing societies, alongside the rapid growth of tertiary-sector employment is a likely culprit in rising inequality in such societies. The greater heterogeneity of the rapidly growing service sector, from high-end information technology services to informal retail services, has long been argued to have contributed to the upswing in inequality in developed societies (e.g., Levy and Murname 1992; Singelmann et al. 1993; Alderson and Nielsen 2002). In sum, then, the post-industrial-transition world that we have moved into is one in which there is very little evidence that economic development will, in the near term, result in a reduction in inequality within the typical society, developed and developing alike.

\section{BETWEEN-COUNTRY INCOME INEQUALITY}

If income inequality has been rising within the typical society, what of inequality between countries? In fact, much of the debate over recent trends in global inequality has centered precisely on the between-country component (Korzeniewicz and Moran 1997; 
Firebaugh 1999, 2003; Firebaugh and Goesling 2004; Anand and Segal 2008; Dowrick and Akmal 2005). Recent work on the subject suggests that population-weighted between-country inequality in PPP-adjusted international dollars has been declining since the last decades of the twentieth century (Firebaugh 2003; Sala-i-Martin 2002; Hung and Kucinskas 20II; cf. Clark 20II). However, other scholars have argued that the finding of declining between-country inequality may have been driven by a range of methodological and measurement issues: the choice of index in PPP construction (Dowrick and Akmal 2005; Anand and Segal 2008); the use of PPP exchange rates versus market exchange rates (Firebaugh 1999; Korzeniewicz and Moran 2000; Wade 2004; Dowrick and Akmal 2005); population-weighting (Babones 2002; Wade 2004); and the exceptional growth of China (Babones 2002; Clark 2011). In what follows, we compute updated measures of between-country inequality using the latest data from the PWT. We find that between-country inequality has declined, but only since 2000 . We then show that this decline after 2000 is robust to the methodological and measurement issues raised in the literature.

\section{Updates to the Penn World Tables' Treatment of Non-Benchmark Years}

The main data come from the latest PWT. The PWT employs surveys from the International Comparison Program (ICP) to compute PPP-adjusted GDP per capita. Before presenting the updated estimates of between-country inequality, a brief discussion of how the PWT uses the ICP price data is in order. The ICP has conducted seven cross-national price surveys since 1970, with progressively increasing country-coverage (1970, 1975, 1980, 1985, 1996, 2005, 2011). These price surveys provide data on the relative prices of a basket of goods and enable the computation of GDP figures that adjust for relative price levels across countries. This purchasing-power adjustment is designed to provide a more accurate indication of relative standards of living across countries than can be derived using exchange rates. However, the GDP figures for non-benchmark years cannot be estimated directly because relative price data are not available.

In previous versions of the PWT (7 and older), GDP figures for non-benchmark years were estimated by using the single latest ICP benchmark year and then extrapolating using relative national inflation rates for the non-benchmark years. This method is similar to that used by the World Bank to arrive at estimates of GDP per capita in PPP-adjusted (international) dollars. Starting from PWT 8.०, the PPPs are estimated using data not only from the most recent ICP price survey, but also from earlier surveys. PPP estimates are interpolated or extrapolated for each country using the nearest year in which the country participated in an ICP survey. To cite an example from the user guide, if a country participated in the 1996 and 2005 price surveys, PPP data for the years between 1996 and 2005 are interpolated using relative inflation rates such that the PPP estimates for the intervening years are consistent with those in 1996 and 2005. For the years before 1996 and after 2005, PPP data are extrapolated using relative inflation rates. In sum, PWT 9.0 employs information from the latest 20II ICP survey, but also uses information from earlier surveys. This use of all available ICP survey data is a substantial departure from the data used in studies that rely on earlier versions of PWT or World Bank data. ${ }^{6}$ 
Estimates of Population-Weighted Between-Country Inequality using PWT 9.0

Figure 3 presents our calculation of population-weighted between-country inequality in PPP-adjusted GDP per capita for three different samples: a series beginning in 1950 with complete data on 6I countries, a series beginning in 1960 with complete data on II countries, and a series beginning in 1970 with complete data on 156 countries. The countries in these series contain, respectively, $74 \%, 87 \%$, and $95 \%$ of world population in 1987 , the approximate midpoint of the data. The 1970 series has considerably more countries than the 1950 sample because GDP per capita data are available for a wider range of countries in later years. It is also worth noting that data on the post-communist countries that split from the Soviet Union are not available in the PWT. Figure 3 suggests a clear pattern in betweencountry inequality, regardless of which sample is used. In the 1970 series, weighted betweencountry inequality oscillates around a Gini of 0.6 and declines steeply after 2000, reaching below 0.5 in 2014. The 1950 and 1960 series suggest a steady upward trend in inequality until 1990, followed by a steep decline after 2000 . In sum, the results presented in Figure 3 suggest that weighted between-country inequality has declined substantially in recent years. However, in contrast to previous studies that documented declines in the last few decades of the twentieth century, we find that inequality only declined appreciably after 2000 . In what follows, we examine whether this decline in between-country inequality is sensitive to PPP construction, choice of PPPs over exchange rates, population weighting, or the inclusion of China.

\section{Construction of PPP Rates: Penn World Table versus World Bank Data}

Among other differences between the two main data sources used to measure betweencountry inequality, the PWT and the World Bank use different methods to construct PPP

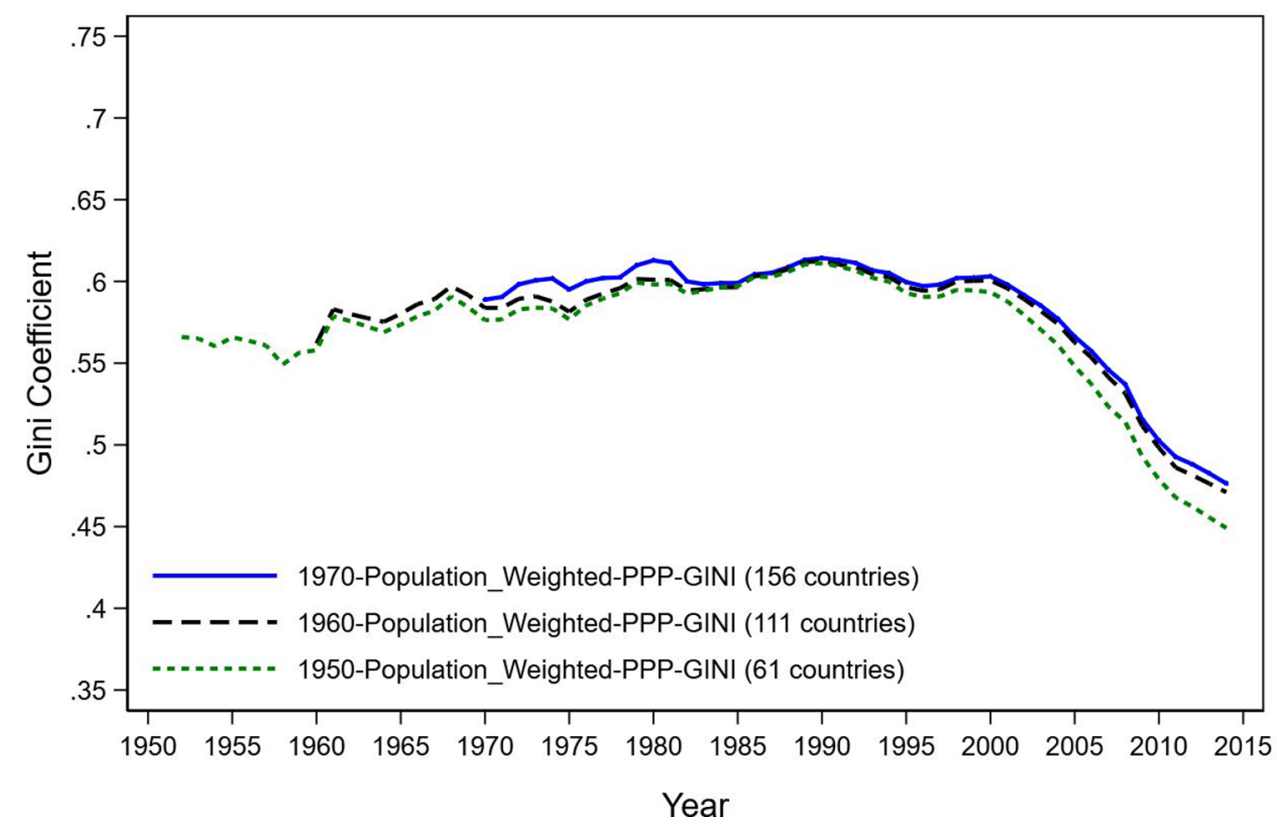

FIGURE 3. Trend in Population-Weighted Between-Country Inequality 
rates. Traditionally, the PWT has used the Geary-Khamis (GK) index method, while more recent World Bank data relies on the Eltetö-Köves-Szulc (EKS) method. This is, potentially, an important difference, as it is the PPP rate, of course, that renders GDP figures comparable. Research has shown that the GK index method overestimates the real income of poorer nations and biases estimates of international inequality downward (Dowrick and Akmal 2005; Anand and Segal 2008). The EKS method does not suffer from this form of bias. From PWT 8.0 onward, a combination of EKS and GK methods are used to arrive at PPP-adjusted GDP figures. In contrast, the World Bank does not use GK index methods. Also, as mentioned earlier, the PWT uses information from previous ICP price surveys while the World Bank only uses the information from the latest ICP survey (2011). Previous work has shown that the calculation of trends in between-country inequality is sensitive to the choice of index method (Dowrick and Akmal 2005; Anand and Segal 2008). For example, Dowrick and Akmal (2005) show that between-country inequality declines between I980 and 1997 when using the PWT's older GK index method for PPP construction and that when the substitution bias associated with the GK index method is corrected, there is no discernible change in inequality.

To address these concerns, we compare the trends in population-weighted betweencountry inequality using both PWT 9.0 and World Bank data. World Bank PPP-adjusted GDP figures are only available from 1990 onward. Also, the sample of countries available in the World Bank data is different from that contained in the PWT. Therefore, the final sample of countries for this comparison is reduced to the 138 countries available in both sources. Figure 4 plots the trends in weighted between-country inequality using both data sources from 1990 onward. The plots suggest no major differences in trends in inequality in the last

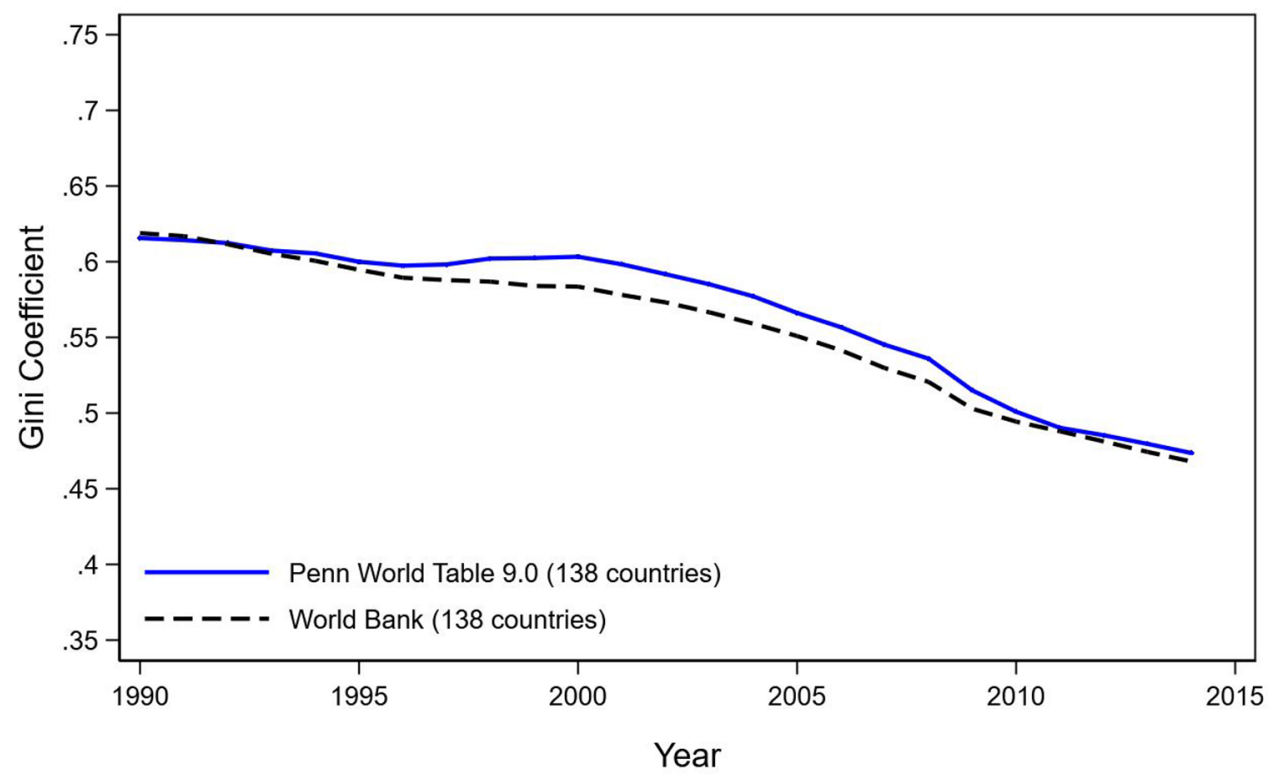

FIGURE 4. Trend in Population-Weighted Between-Country Inequality: Penn World Tables and World Bank PPP Methods Compared 
25 years. The World Bank data suggest that inequality started to decline earlier than what the PWT data indicate, but both suggest substantively meaningful declines in inequality, on the order of over Io Gini points. In sum, Figure 4 indicates that the choice of data source and PPP index method is not driving the post-2000 decline in between-country inequality we observed above.

\section{Purchasing Power Parity or Market Exchange Rates}

Another point of contention in the literature on global inequality has concerned the choice of whether to use PPP exchange rates or official market exchange rates to convert currencies (Firebaugh 1999; Korzeniewicz and Moran 2000; Arrighi, Silver, and Brewer 2003). Put simply, PPP exchange rates take into account domestic price differences between countries while market exchange rates do not. The decision to use one over the other hinges on the type of question we are interested in. If we are interested in comparing average levels of welfare across countries, the use of market exchange rates would tend to underestimate the real income of individuals in poorer countries because prices for goods and services are generally lower in poorer countries (Firebaugh 1999; Melchior and Telle 200I). In this case, the use of a consumption-based PPP exchange rate would better capture differences in standards of living. However, if we are interested in a measure of the "relative command that inhabitants of different countries have [over world income]," then the use of market exchange rates would be more appropriate (Korzeniewicz and Moran 1997:I0II; Arrighi, Silver, and Brewer 2003). Most importantly, prior research suggests that the decision to use PPPs or market exchange rates matters crucially for the conclusions we draw about trends in international inequality (Firebaugh 1999).

In Figure 5, we examine whether the use of official market exchange rates in the computation of population-weighted between-country inequality affects our conclusions about the trend in inequality. Figure 5 reproduces the original weighted between-country inequality series using PPP GDP per capita figures along with another series that uses market exchange rate GDP per capita. Both plots are for the 1970 sample of 156 societies. While the measured level of between-country inequality is higher when market exchange rates are used, the dynamics are very similar. By the market exchange rate series, between-country inequality starts to gradually decline in the early I990s before declining more sharply after 2000 . While the extent of the decline is less pronounced in the market exchange rate series than in the PPP series, our analysis indicates that-regardless of how we conceptualize between-country inequality, either as disparities in welfare conditions or disparities in the command over world income-inequality has declined since 2000.

\section{Population-Weighting}

Milanovic (2013a) distinguishes between "Concept I" and "Concept 2" versions of between-country international inequality. Concept $\mathrm{I}$ inequality is simple international inequality (i.e., inequality in average income between countries) while Concept 2 inequality is population-weighted inequality between countries. In other words, the unit of analysis in Concept I inequality is the country, while the unit of analysis in Concept 2 inequality is the average individual. In Concept $\mathrm{I}$, each country is given equal weight in the 


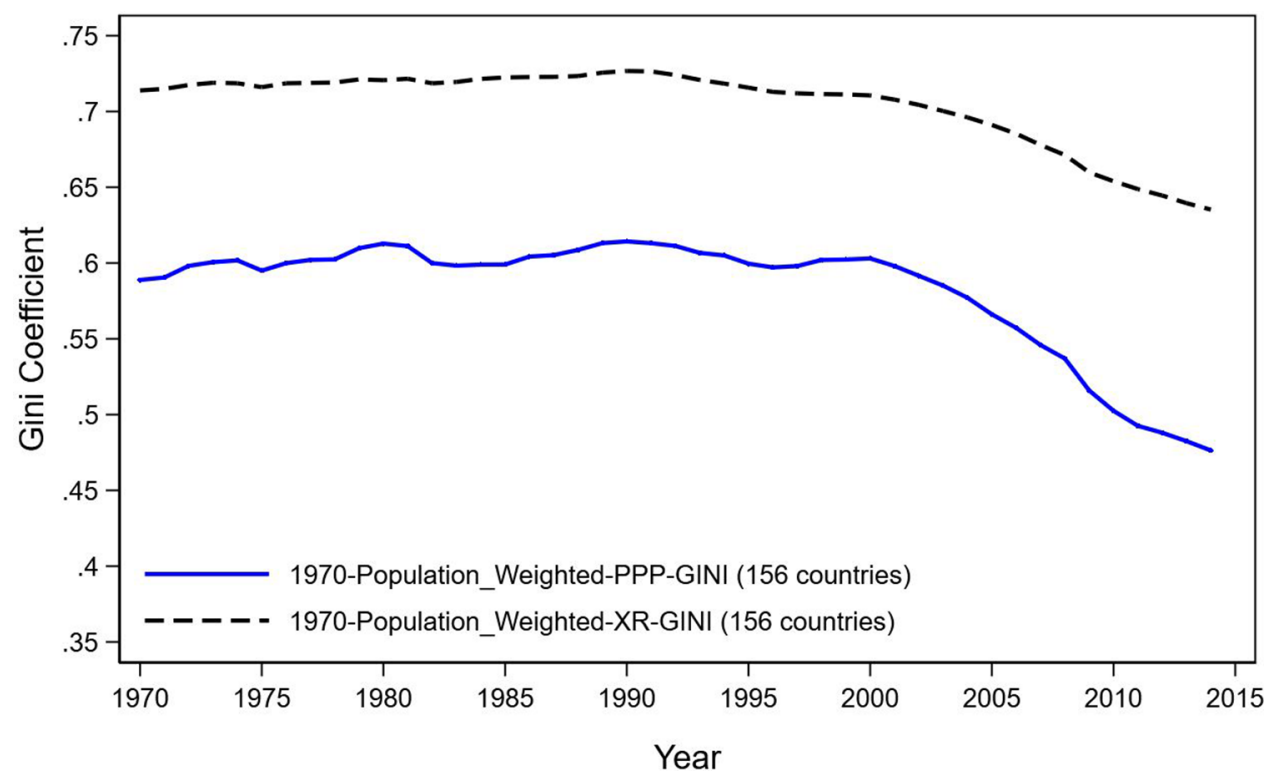

FIGURE 5. Trend in Population-Weighted Between-Country Inequality: PPP and Market Exchange Rate Methods Compared

computation of the dispersion measure, so that, for example, China and Qatar have the same weight. This unweighted measure of inequality is particularly useful when we are interested in convergence/divergence processes between countries or comparing the performance of different economies. For example, analyses that employ a world-systems perspective and are interested in the mobility of nation-states in the world-economy typically use unweighted GDP per capita figures (Wallerstein 2004; Babones 2005; Clark 2016). As Babones (2002) demonstrates, trends in unweighted international inequality do not necessarily have to follow trends in populationweighted between-country inequality. Indeed, if the decline in population-weighted inequality after 2000 is being driven by a handful of high-growth, populous countries, unweighted inequality could still be increasing. In Figure 6, we examine whether the decline in between-country inequality we observe after 2000 in Figure 3 is the result of population-weighting.

Figure 6 displays trends in unweighted between-country inequality for the 1950 and 1960 samples using both PPP rates and market exchange rates. In both of the PPP samples, between-country inequality, while fluctuating from year to year, generally increases until 2000 and declines thereafter. The two exchange rate series are a bit more difficult to characterize, suggesting that, by this measure, simple international inequality-which we know had been rising for centuries-had plateaued or hit a ceiling in the late twentieth century. Here too, however, we see a small decline of a few Gini points after 2000 . Overall, the results presented in Figure 5 suggest that Concept $\mathrm{I}$ inequality (i.e., unweighted international inequality) has declined along with Concept 2 inequality (i.e., weighted between-country inequality) in the last two decades or so. 


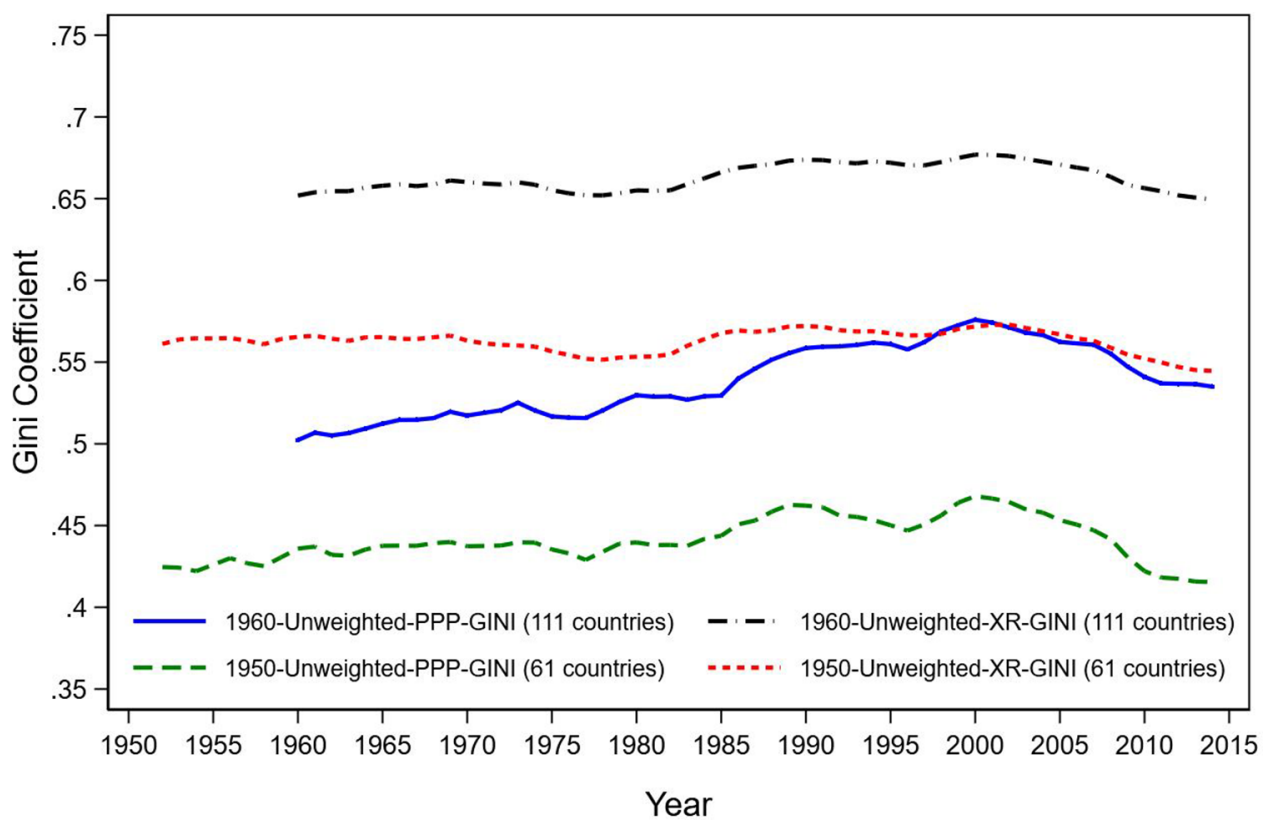

FIGURE 6. Trend in Unweighted International (Between-Country) Inequality

\section{The "Chindia" Effect}

China has maintained a growth rate that is consistently above the world average for the past four decades (World Bank 2017; Hung 2015). Several studies have suggested that, owing to its large population, population-weighted between-country inequality is highly sensitive to the inclusion/exclusion of China (Peacock, Hoover, and Killian 1988; Schultz 1998; Melchior and Telle 200I; Clark 20II; Hung and Kucinskas 20II). For example, Clark (2011) finds that with the inclusion of China, between-country inequality declined between 1990 and 1999 and, with China excluded, between-country inequality increased across the same period. Similarly, Hung and Kucinskas (201I) find that, between 1980 and 2004, between-country inequality declined with China and India included, but, when both countries are excluded, inequality increased until 2000 before leveling out.

Given the likely outsized influence of very large countries such as China and India on our measurement of weighted between-country inequality, it is worthwhile to examine their effect on the trend in inequality we observed in Figure 3. Figure 7 thus displays three series using the 1970 sample: the weighted between-country inequality for the full sample; with China excluded; and with both China and India excluded. China and India have meaningful effects on both the level and trajectory of between-country inequality. With the exclusion of China, and both China and India, inequality is lower in 1970, increases until around 2000, and then generally declines thereafter. The exclusion of China and India, interestingly enough, would lead us to underestimate inequality for much of the latter part of the twentieth century and to underestimate the extent of the decline in between-country inequality in the twenty-first century. That said, it is also clear that, even if one were inclined to exclude over $36 \%$ of the world's population (as of 2014 ) and two of the fastest-growing 


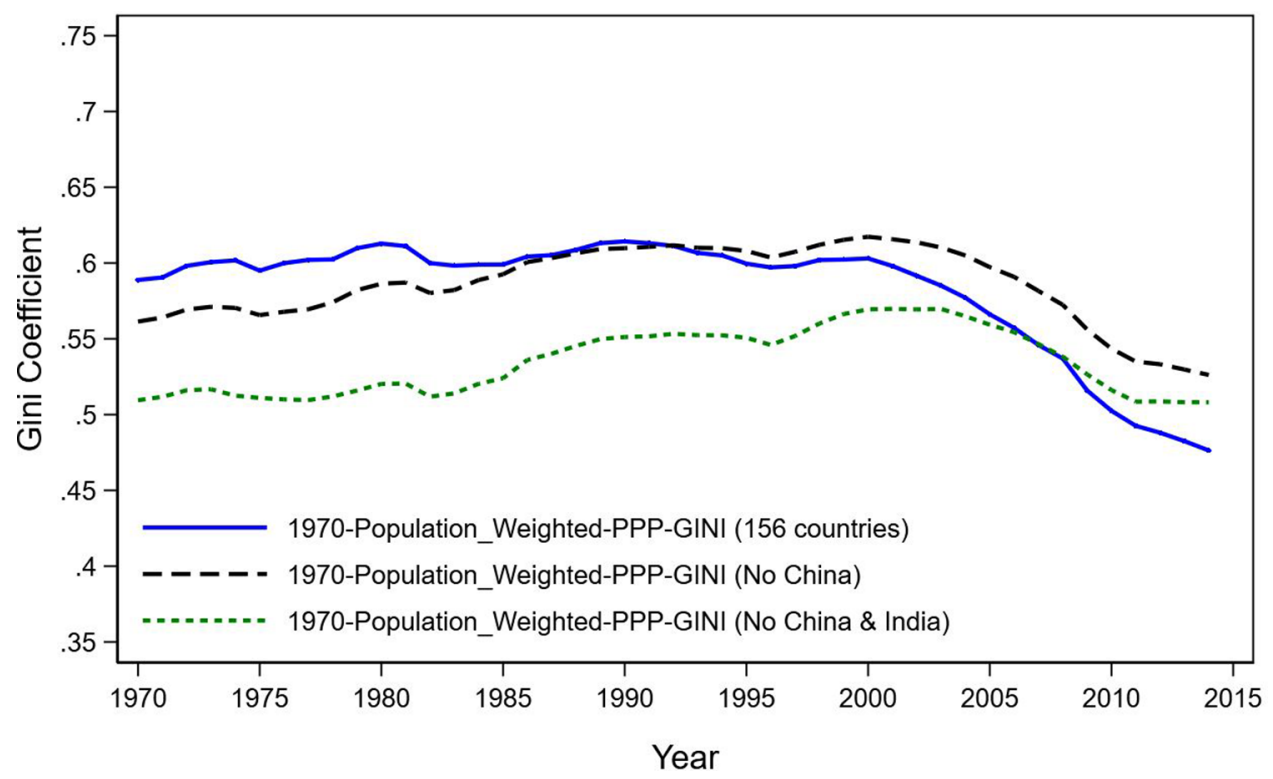

FIGURE 7. The "Chindia Effect": Trend in Population-Weighted Between-Country Inequality without China and without China and India

large economies from the calculation of inequality, population-weighted between-country still measurably declined in recent years.

\section{The Gap between the Rich and the Rest}

Our examination of weighted between-country inequality reveals a real reduction in inequality after 2000. Much of the literature on global inequality and development has, at least implicitly, been concerned with convergence/divergence between the "Rich" and the "Rest" (Amsden 2001; Arrighi, Silver, and Brewer 2003; Firebaugh and Goesling 2004). As our results imply convergence in average real incomes in recent decades, we explicitly illustrate this, comparing historically rich advanced economies to other countries in the 1970 sample.

Figure 8 displays the trends in average PPP-adjusted GDP per capita from the PWT. These average real income trends are weighted by each group's/country's population size such that, for instance, China has a larger weight in the computation of the average income series for the Rest group than does Sri Lanka. The Rich country sample consists of all countries in Western Europe, the U.S., Canada, New Zealand, Australia, and Japan. Figure 8 also displays the trend in average real income for China and India alone. Figure 9 presents two series based on the information in Figure 8: the difference in average real income between rich and other countries, and the ratio between the two.

A few facts stand out. The series for the Rich in Figure 8 is visibly responsive to the business cycle, showing declines in response to the global recessions of the mid-1970s, the early I980s, and 2008. Otherwise, average real income rises continuously from 1970 to 2014 . In contrast, the series for the Rest in Figure 8 is comparatively flat across the 1970s, I980s, and into the I990s, after which average incomes begin to tick up, undoubtedly helped along by China, which moves from having below-average income for the Rest to above-average by the 


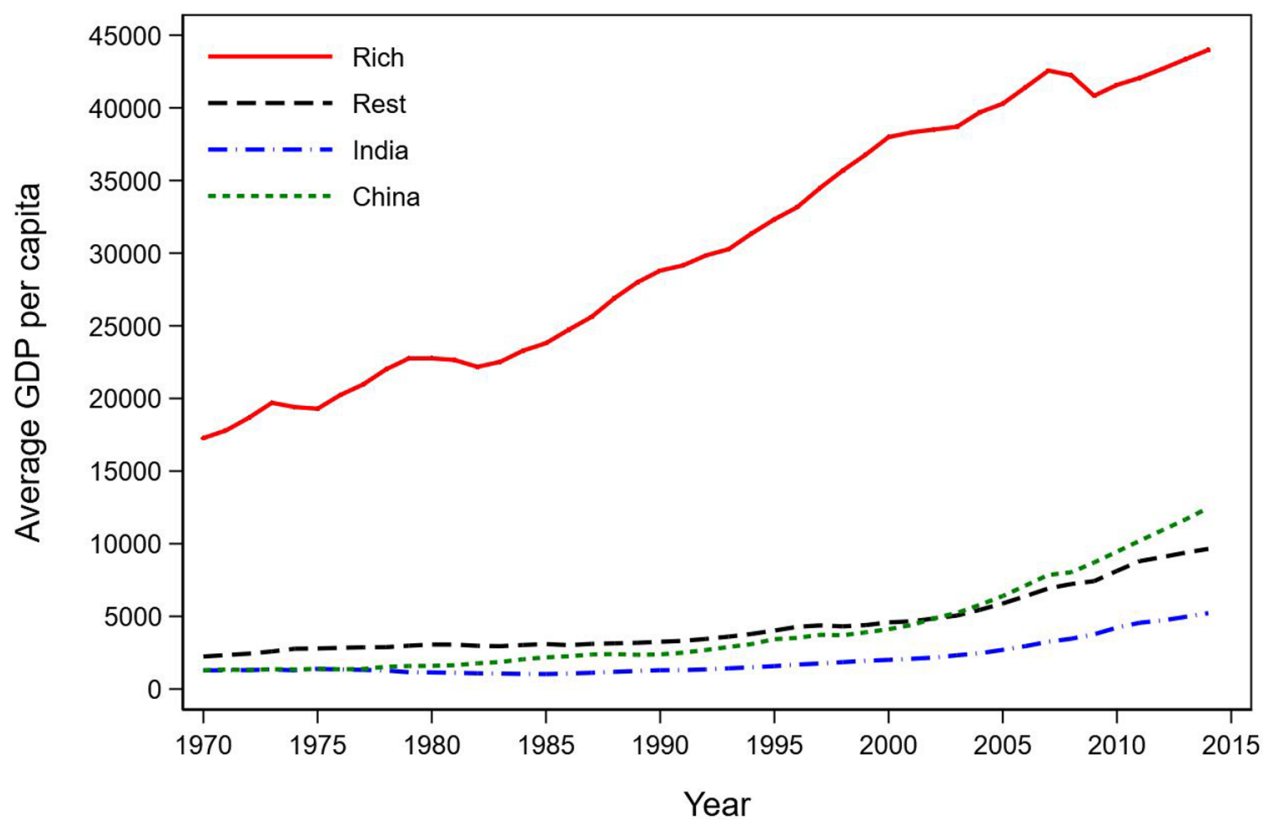

FIGURE 8. Trend in Average Real Income: The Rich, the Rest, China, and India

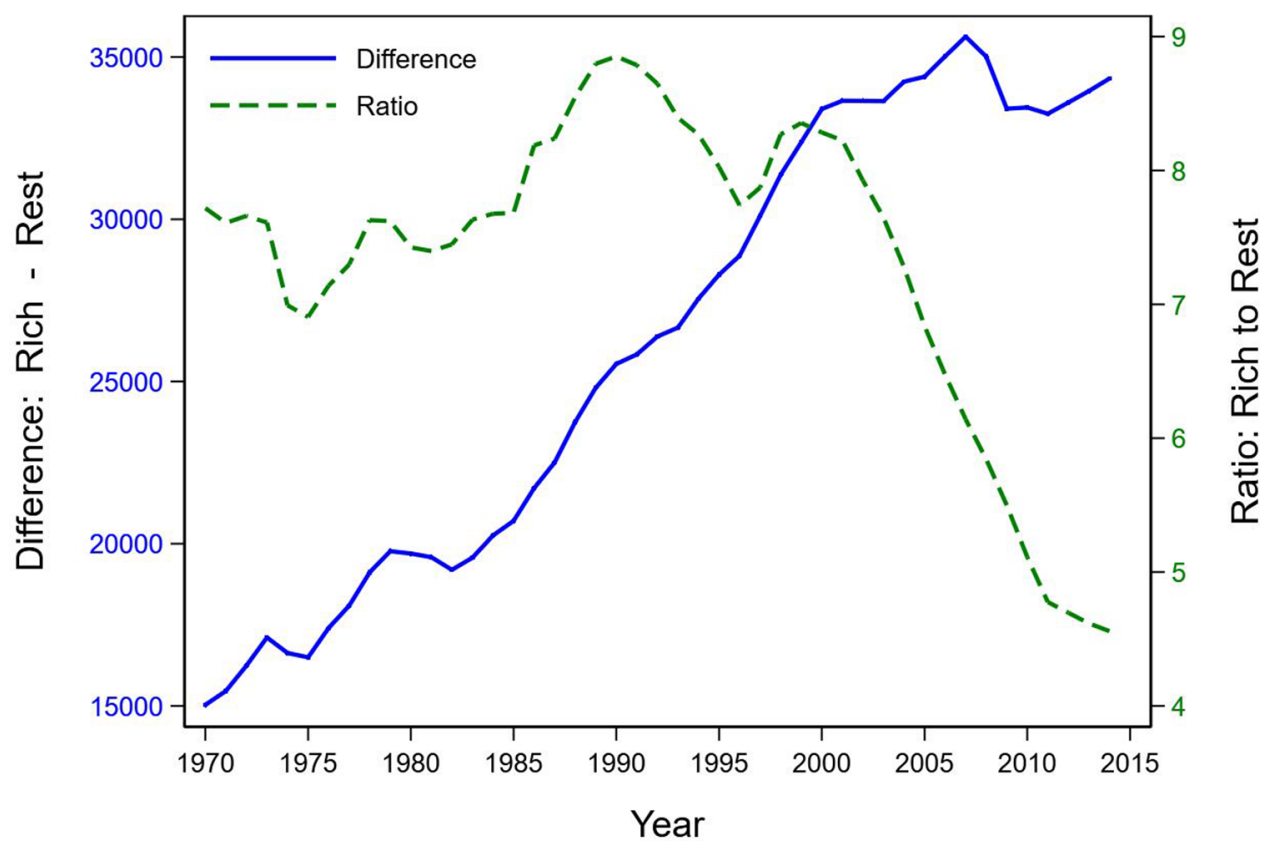

FIGURE 9. Trend in the Difference in Average Real Income between the Rich and the Rest and the Ratio of the Income of the Rich to the Rest 
early 2000s. Turning to Figure 9, the difference in average real income between the Rich and the Rest increased from just over $\$ 15,000$ in 1970 to more than $\$ 33,000$ in 2014 (2011 USD), following a decline and partial recovery after 2008. However, the income of the Rich relative to the Rest fell precipitously after 2000, from being 8.3 times larger in 2000 to 4.6 times larger in 2014 . Given that average real income in both groups was higher in 2014 than in 2000 , this is clear evidence that the Rest have been growing faster than the Rich for all of the present century. Thus, in addition to representing a significant break in inequality, the post-2000 era represents a critical shift in the divergence/convergence dynamics between historically rich and other countries.

\section{"TRUE" GLOBAL INEQUALITY}

Over simple international inequality (i.e., unweighted between-country inequality), weighted between-country inequality represents a significant step toward an ideal measure of global inequality (i.e., one based on information on every income-receiving unit-individual, household, or family-in the world). Instead of treating, for instance, China as equivalent to the Seychelles, population-weighting gives China more than I4,500 times the influence of the Seychelles in the calculation of between-country inequality. It is, nevertheless, inherently limited as a measure of global inequality. In weighting GDP per capita by population, one, in effect, gives all members of the society the same income. All 96,000 people in the Seychelles are given the same income, the income per capita of the Seychelles, and all I. 4 billion Chinese are given the same income, the income per capita of China. That is, weighted between-country inequality is a crude approximation of true global inequality, as it assumes there is no inequality of income within countries. Therefore, what the results presented in Figure 3 in fact represent is a measure of the lower bound of global inequality in each year. They represent the lower bound because we know, of course, that there is inequality to varying degrees within each society. Looking back to Figure 3, what this tells us, for example, is that global inequality in 2014 could not possibly have been any lower than around 0.45 or 45 Gini points. We know it could not be any lower than that, but we really don't know how much higher it might be-or how much higher global inequality would be if we factored in within-country inequality, which, as we saw, has been growing in the typical society in recent decades.

The fact that population-weighted between-country inequality represents a lower bound raises the question of what the upper bound of global inequality might be. As Milanovic (2013b) has shown, it is easy to calculate this. One can estimate the upper bound or ceiling of global inequality in a given year by relating subsistence income to average income. That is, assume a world in which all but a minuscule elite live on the World Bank's international poverty line of $\$$ I.90 a day, or $\$ 693.50$ a year (201 I USD). One can use per capita income data to calculate the Gini coefficient of inequality under those conditions as:

$$
\text { Maximum Gini }=\alpha-1 / \alpha
$$

where $\alpha$ is the ratio between mean and subsistence income. By this formula one can see that if mean income is low, the maximum possible Gini will be low, because the surplus 
available to the elite is small. As average income grows, however, the maximum possible Gini will approach 1.0 as the surplus that could be captured by the elite grows.

Estimates of the upper bound of global inequality are presented in Figure io using the 1960 series. In this figure, we also reproduce the 1960 and 1970 series of weighted between-country inequality. By this measure, a maximally unequal world of 1960 could have had a Gini coefficient no higher than about 0.83 . As average real incomes have grown, potential global inequality has likewise grown, and, by 2014, a maximally unequal world in which nearly everybody lived on \$I.9O a day could have had a Gini coefficient no higher than 0.95 . Tracing out this theoretical maximum is helpful as it provides some bounds for our estimates of "true" global inequality. We know that global inequality can be no higher than what we see in Figure Io. Likewise, we know that global inequality can be no lower than the bounds traced out by weighted between-country inequality. Thus an estimate of global inequality of, say, 0.82 in 2014 simply lacks face validity; it is too close to what we would see in a maximally unequal world. Similarly, an estimate of 0.47 in 2014 is simply too low; it is too close to what we would see in a world in which the only source of income inequality is differences in average income between countries. The true value must lie somewhere between these extremes.

Milanovic's work gets us as close as we have come to date to the ideal of having information on every income-receiving unit in the world. Milanovic's estimates of global inequality are based on household income surveys that are generalizable to over $80 \%$ of the world's population in all years. ${ }^{8}$ The data we present in Figure 10 are drawn from Milanovic and Roemer (2016). They use the same 20I PPPs that we have used throughout, allowing

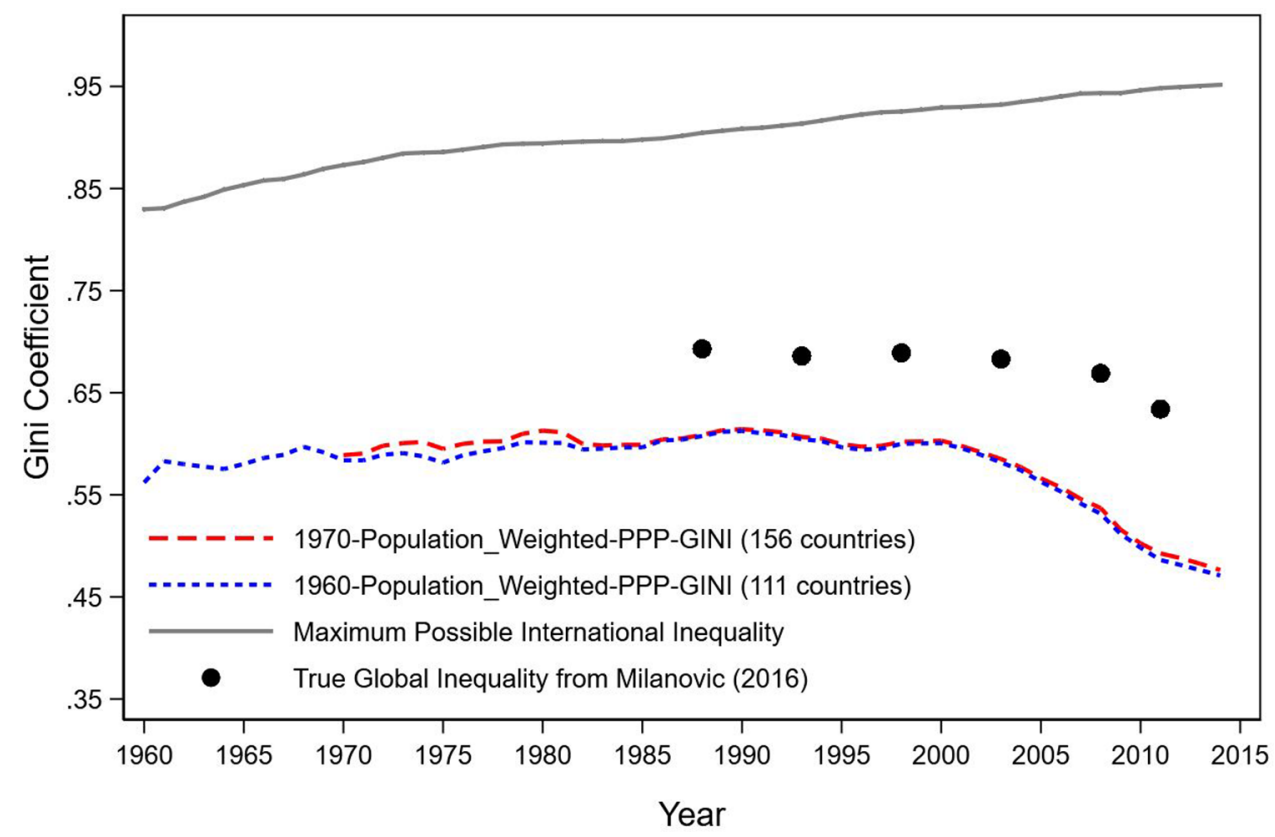

FIGURE 10. Estimates of True Global Inequality and the Trends in Maximum Possible Inequality and Weighted Between-Country Inequality 
an "apples to apples" comparison of their estimates to our upper and lower bounds of global inequality. Estimates of true global inequality roughly mirror the trajectory of weighted between-country inequality, being more or less stable across the late I980s and I990s, but turning to decline thereafter. The decline in global inequality between 1998 and $201 \mathrm{I}$ is substantively meaningful, 5.5 Gini points. In terms of the two-person cake-sharing game described above, the decline of 5.5 Gini points is equivalent to the person receiving the smaller slice in 1998 receiving $2.75 \%$ more cake by 201 . Given the slow pace at which income inequality typically changes-"like watching the grass grow," as Aaron (1978) famously quipped-this is a remarkable shift for 13 years (especially when one recalls that the changes underlying this shift have moved tens of millions out of absolute poverty). It is also interesting to note the growing divergence between our best estimates of true global inequality and the trend in maximum possible inequality in Figure Io. As the world has gotten richer, the amount of inequality that could be produced or extracted in the world system has grown, but the proportion produced (i.e., true global inequality/maximum possible inequality) is declining, and notably so after 2000. Thus, even though inequality has been growing within the typical society, we have moved meaningfully further away from a world in which all but a tiny minority live on the edge of subsistence.

\section{CONCLUSIONS}

To recapitulate, using the latest available data on within- and between-country inequality, we find that inequality within countries has been on the rise and argue that there is little reason to expect in the near term that further economic development will result in a reduction in inequality within the typical society, whether developed or developing. Inequality between countries continued to grow for much of the latter half of the $20^{\text {th }}$ century, as it had for the last few centuries, but turned to decline measurably after 2000 . We have demonstrated that this decline is robust to the methodological and measurement issues raised in the literature and argued that it is primarily attributable to the now familiar improvement in average incomes in a number of developing societies. Tracing out the lower and upper bounds of global inequality, we then situated estimates of true global inequality within them. The data available on true global inequality suggest stability, then a substantively meaningful decline, again, around the turn of the century.

Having detailed what is really happening with global inequality, we conclude with a number of thoughts on what we think it really means looking forward. First, in a postindustrial-transition world-one in which further economic development cannot be expected to result in reductions in inequality within societies-most of the "action" on the inequalityreduction front is likely to be "global." That is, if we are going to see further reduction in global inequality in the near term, it is probably going to be the result of continued international trade, investment, and migration producing rising average incomes in developing societies, rather than the moderation of inequality within countries. Second, it is clear, in practice, despite much discussion to the contrary, policy makers have largely overlooked the stakes involved for their constituents. As we noted earlier, what country you live in remains, by a large margin, the single biggest determinant of your income. This is of 
course, a pure accident of birth for the vast majority. As Milanovic (2015) has shown, on a global level there is precious little "equality of opportunity:" those who live in rich countries enjoy massive rents on citizenship, rents that very few are prepared to forgo. Third, it is plainly not obvious to all that globalization has always represented a Pareto improvement; that is, it is not obvious to all that global trade and investment have made hundreds of millions people in developing societies better off without making other people-the middle and working classes of the rich countries-worse off. It is thus not at all surprising that the factors underlying the trends we document in this paper have spawned a political constituency in both the Global North and South that is strongly opposed to globalization. Members of that constituency feel that they have a lot to lose-and many certainly do-and they feel as if they have been losing. To our minds, further reductions in global inequality that rely on the primary mechanism (i.e., globalization) through which this has occurred in recent decades may turn critically on the ability of policymakers to devise ways of ensuring that globalization is more broadly experienced and viewed as welfare enhancing. As happened with the last great round of globalization in the late nineteenth and early twentieth centuries (Chase-Dunn, Kawano, and Brewer 2000), the window can close as just as quickly as it opened.

That said, the role of globalization in current and future inequality reduction is multifaceted and must be approached critically. For instance, while the latest data indicate a substantial decline in between-country and global inequality after 2000 , it is important to note that this is well after the onset of the most recent round of globalization (as conventionally dated) and later than earlier studies had indicated. This may reflect the fact that the pathways through which globalization shapes the growth trajectories of nations varies. While the role of export-led industrialization in China's growth is clear, manufactured exports have played a relatively minor role in India's growth story in the past decade. India's growth has been driven more by domestic consumption fueled by foreign capital inflows (Ghosh and Chandrasekhar 2009; Hung 2015). The experiences of individual nations suggest that the case for simply increasing trade and foreign investment (especially short-term capital flows) is not always unambiguously positive. To be sure, globalization has been important in the export-led take-off of China and, before then, the East Asian Tigers like South Korea and Taiwan. In contrast to the earlier success stories of East Asian countries, China has had a particularly large impact on reducing global inequality because of its size. However, it is also important to remember that these countries did not embrace trade liberalization blindly. As the large literature on developmental states reveals, late industrializers engaged in a more selective integration with the world economy (Amsden 200I; Johnson 1982; Chang 2006; Hung 2015). Furthermore, financial liberalization that encourages short-term capital flows and speculation can lead to instability and crises, like the East Asian financial crisis in the late I990s. And the competitive shock associated with the entry of Asian countries like China into export markets can "close out" other developing countries (Kaplinsky 2005; Rodrik 2016). In sum, the process of globalization that has played an important role in the rapid growth of some developing countries has not engendered the same in other developing countries, nor can it be assumed that it will do so in the future. 


\section{WORKS CITED}

Aaron, Hentry. 1978. Politics and the Professors: The Great Society in Perspective. Washington D.C.: Brookings Institution.

Ahluwalia, Montek S. 1976. "Income Distribution and Development: Some Stylized Facts." American Economic Review 66:128-35.

Alderson, Arthur S., and François Nielsen. 2002. "Globalization and the Great U-Turn: Income Inequality Trends in 16 OECD Countries." American Journal of Sociology 107:1244-1299.

Amsden, Alice H. 2001. The Rise of "the Rest": Challenges to the West from Late-Industrializing Economies. Oxford: Oxford University Press.

Anand, Sudhir, and Paul Segal. 2008. "What Do We Know about Global Income Inequality?” Journal of Economic Literature 46:57-94.

Arrighi, Giovanni, Beverly Silver, and Benjamin Brewer. 2003. "Industrial Convergence, Globalization, and the Persistence of the North-South Divide." Studies in Comparative International Development 38:3-31.

Babones, Salvatore. 2002. "Population and Sample Effects in Measuring International Income Inequality." Journal of World-Systems Research 8:8-28.

Babones, Salvatore. 2005. "The Country-Level Income Structure of the World-Economy." Journal of World-Systems Research 11:29-55.

Barro, Robert. 2008. "Inequality and Growth Revisited." Working Paper Series on Regional Economic Integration 11:1-14. Manila, Philippines: Asian Development Bank.

Bluestone Barry. 1990. "The Great U-Turn Revisited: Economic Restructuring, Jobs, and the Redistribution of Earnings." Pp. 7-43 in Jobs, Earnings, and Employment Growth Policies in the United States, edited by John D. Kasarda. Boston, MA: Kluwer.

Bourguignon, François, and Christian Morrisson. 2002. "Inequality among World Citizens: 18201992." American Economic Review 92:727-44.

Brady, David, Yunus Kaya, and Gary Gereffi. 2011. "Stagnating Industrial Employment in Latin America." Work \& Occupations 38(2):179-220.

Chase-Dunn, Christopher, Yukio Kawano, and Benjamin D. Brewer. 2000. "Trade Globalization since 1795: Waves of Integration in the World-System." American Sociological Review 65:77-95.

Chang, Ha-Joon. 2006. The East Asian Development Experience: the Miracle, the Crisis and the Future. London: Zed Books.

Clark, Rob. 2011. "World Income Inequality in the Global Era." Social Problems 58(4):565-592.

Clark, Rob. 2016. "Examining Mobility in International Development." Social Problems 63(3):329-350.

Coady, David, and Allan Dizioli. 2017. "Income Inequality and Education Revisited: Persistence, Endogeneity, and Heterogeneity." Working Paper No. 17/126. Washington, DC: International Monetary Fund.

Cornia, Giovanni Andrea, Tony Addison, and Sampsa Kiiski. 2003. "Income Distribution Changes and their Impact in the Post-World War II Period.” UNU/WIDER Discussion Paper No. 2003/28. Helsinki, Finland.

Deininger, Klaus, and Lyn Squire. 1998. "New Ways of Looking at Old Issues: Inequality and Growth." Journal of Development Economics 57:259-87.

Dowrick, Steve, and Muhammad Akmal. 2005. "Contradictory Trends in Global Income Inequality: A Tale of Two Biases." Review of Income and Wealth 51:201-229.

Feenstra, Robert C., Robert Inklaar and Marcel P. Timmer. 2015. "The Next Generation of the Penn World Table." American Economic Review 105(10):3150-3182, available for download at www. ggdc.net/pwt.

Fields, Gary S. 2001. Distribution and Development: A New Look at the Developing World. New York: Russell Sage Foundation.

Firebaugh, Glenn. 1999. "Empirics of World Income Inequality." American Journal of Sociology 104:1597-1630. 
Firebaugh, Glenn. 2003. The New Geography of Global Income Inequality. Cambridge, MA: Harvard University Press.

Firebaugh, Glenn, and Brian Goesling. 2004. "Accounting for the Recent Decline in Global Income Inequality.” American Journal of Sociology 110:283-312.

Galbraith, James K. 2011. "Inequality and Economic and Political Change: A Comparative Persepective." Cambridge Journal of Regions, Economy and Society 4:13-27.

Goesling, Brian. 2001. "Changing Income Inequalities within and between Nations: New Evidence." American Sociological Review 66:745-61.

Ghosh, Jayati, and C. P. Chandrasekhar. 2009. "The Costs of Coupling: The Global Crisis and the Indian Economy.” Cambridge Journal of Economics 33:725-739.

Harrison, Bennett, and Barry Bluestone. 1988. The Great U-Turn. New York: Basic Books.

Hung, Ho-Fung, and Jaime Kucinskas. 2011. "Globalization and Global Inequality: Assessing the Impact of the Rise of China and India, 1980-2005." American Journal of Sociology 116:1478-1513.

Hung, Ho-Fung. 2015. The China Boom: Why China Will Not Rule the World. New York: Columbia University Press.

International Labour Organization. 2018. ILOSTAT database. Retrieved February 21, 2018.

Johnson, Chalmers. 1982. MITI and the Japanese Miracle: the Growth of Industrial Policy: 1925-1975. Stanford, CA: Stanford University Press.

Kaplinsky, Raphael. 2005. Globalization, Poverty and Inequality: Between a Rock and a Hard Place. Malden, MA: Polity.

Korzeniewicz, Roberto P., and Timothy P. Moran. 1997. "World-Economic Trends in the Distribution of Income, 1965-1992." American Journal of Sociology 102:1000-39.

Korzeniewicz, Roberto P., and Timothy P. Moran. 2000. "Measuring World Income Inequalities." American Journal of Sociology 106:209-14.

Kuznets, Simon. 1955. "Economic Growth and Income Inequality." American Economic Review 45:1-28.

Levy, Frank, and Richard J. Murname. 1992. "U.S. Earnings Levels and Earnings Inequality: A Review of Recent Trends and Proposed Explanations." Journal of Economic Literature 30:1333-81.

Melchior, Arne, and Kjetil Telle. 2001. "Global Income Distribution 1965-98: Convergence and Marginalisation.” Forum for Development Studies 1:75-98.

Milanovic, Branko. 2011. "Global Inequality and the Global Inequality Extraction Ratio: The Story of the Past Two Centuries." Explorations in Economic History 48:494-506.

Milanovic, Branko. 2013a. "Global Income Inequality in Numbers: in History and Now." Global Policy 4:198-208.

Milanovic, Branko. 2013b. "The Inequality Possibility Frontier: Extensions and New Applications." World Bank Policy Research Working Paper 6449. Washington, DC: World Bank.

Milanovic, Branko. 2015. "Global Inequality of Opportunity: How Much of Our Income Is Determined by Where We Live?" Review of Economics and Statistics 97:452-460.

Milanovic, Branko. 2016a. Global Inequality: A New Approach for the Age of Globalization. Harvard University Press, Cambridge, MA.

Milanovic, Branko. 2016b. "Recent Trends in Global Income Inequality and Their Political Implications." Presented at Università Bocconi, November 21, Milan, Italy. Retrieved October 21, 2017. (https://www.unibocconi.eu/wps/wcm/connect/c041eee5-b5da-4fc5-8a7d-97f874d5cc22/Milanovic_ Recent+trends+in+global+income+inequality.pdf?MOD=AJPERES)

Milanovic, Branko, and John E. Roemer 2016. "Interaction of Global and National Income Inequalities" Journal of Globalization and Development 7:109-115.

Moller, Stephanie, Arthur S. Alderson and François Nielsen. 2009. "Changing Patterns of Income Inequality in U.S. Counties, 1970-2000.” American Journal of Sociology 114:1037-1101.

Nielsen, François. 1994. "Income Inequality and Industrial Development: Dualism Revisited." American Sociological Review 59:654-77. 
Nielsen, François, and Arthur S. Alderson. 1995. "Income Inequality, Development, and Dualism: Results from an Unbalanced Cross-National Panel.” American Sociological Review 60:674-701.

Peacock, Walter, Greg Hoover, and Charles Killian. 1988. "Divergence and Convergence in International Development: A Decomposition Analysis of Inequality in the World System." American Sociological Review 53:838-52.

Pomeranz, Kenneth. 2001. The Great Divergence: China, Europe, and the Making of the Modern World Economy. Princeton, NJ: Princeton University Press.

Rodrik, Dani. 2016. "Premature Deindustrialization." Journal of Economic Growth 21:1-33.

Sala-i-Martin, Xavier. 2002. "The Disturbing 'Rise' of Global Income Inequality.” NBER Working Paper no. 8904. Cambridge, MA.

Schultz, T. Paul. 1998. "Inequality in the Distribution of Personal Income in the World: How It Is Changing and Why." Journal of Population Economics 11:307-44.

Subramanian, S. 2002. "An Elementary Interpretation of the Gini Inequality Index." Theory and Decision 52:375-379.

Singelmann, Joachim, Forrest A. Deseran, F. Carson Mencken, and Jiang Hong Li. 1993. "What Drives Labor Market Growth: Economic Performance of Labor Market Areas: 1980-86.” Pp. 33-49 in Inequalities in Labor Market Areas, edited by Joachim Singlemann and Forrest A. Deseran. Boulder, Colo.: Westview Press.

UNU-WIDER. 2017. "World Income Inequality Database (WIID3.4)," January 2017.

Wade, Robert H. 2004. "Is Globalization Reducing Poverty and Inequality?" World Development 32:567-589.

Wallerstein, Immanuel M. 2004. World-Systems Analysis: An Introduction. Durham, NC: Duke University Press.

World Bank. 2008. Global Purchasing Power Parities and Real Expenditures - 2005 International Comparison Program. Washington, DC: World Bank.

World Bank. 2017. "World Development Indicators" Washington, DC. World Bank. Retrieved January 6, 2017 (https://data.worldbank.org/indicator/SP.POP.TOTL)

\section{NOTES}

Direct all correspondence to Arthur S. Alderson, Department of Sociology, Indiana University, Ballantine Hall 744, Bloomington, IN 47405. Email for Alderson: aralders@indiana.edu. Email for Pandian: rpandian@indiana.edu.

I. This would be an ideal situation for the study of global inequality. Barring such a global census, it would be ideal to have regular, high-quality income surveys of all countries in the world. Neither, to date, exist; in a real sense, the various estimates of global inequality that we produce and discuss below retrace the history of the (always limited, but increasingly successful)attempts of social scientists to approximate this ideal.

2. The Gini coefficient is a measure of inequality that varies between $\circ$ and $\mathrm{I}$, with $\circ$ representing perfect equality (i.e., all income-receiving units receive the same income) and I representing perfect inequality (i.e., one income-receiving unit receives all of the income). Thus a change of "s Gini points" represents a change in the Gini of 0.05 (or, when multiplied by 100 as in Figures I and 2 below, a change of 5 ).

3. See Nielsen (1994) for an illustration and Nielsen and Alderson (1995) for an application.

4. Data in the WIID are of widely varying quality and there are a host of measurement issues that one must address to treat the data as comparable. Given that Figures I and 2 are intended only to illustrate a few key points over which there is very little doubt, we forgo the usual rules of good practice and simply present all of the data for the 1960s and 20Ios in the latest release of the WIID.

5. This is not to suggest that the general mechanism identified by Kuznets cannot help us make sense of rising inequality. For instance, in the course of the spread of education, one would expect inequality 
to rise, then fall, given that the heterogenity of educational attainment will likewise increase, then decrease, as the population shifts from low to high levels of formal schooling (Moller, Alderson, and Nielsen 2008; Coady and Dizioli 2017). See also Milanovic (2016a) on "Kuznets cycles."

6. For a more detailed description of the updates to PPP construction and other updates to PWT, see Feenstra, Inklaar, and Timmer (2015) or the PWT user guides.

7. For a full description of the differences between the PWT and World Bank PPP-adjusted GDP per capita figures, refer to Feenstra, Inklaar and Timmer (2013) and World Bank (2008).

8. See Milanovic 2016a for details. The surveys employed allow one to draw inferences to between $8 \mathrm{r} \%$ (1988) and $94 \%$ (2003) of world population. 